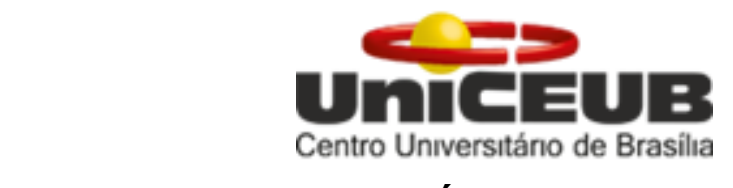

CENTRO UNIVERSITÁRIO DE BRASÍLIA - UniCEUB

PROGRAMA DE INICIAÇÃO CIENTÍFICA

NATÁLIA MARIANA DIÓGENES SILVA DE ALBUQUERQUE JULIANA TERRA RIBEIRO

ANÁLISE COMPARATIVA SOBRE A PERCEPÇÃO DOS ESTUDANTES DE MEDICINA ACERCA DO IMPACTO DAS DISCIPLINAS IESC E HA NO CONTEXTO DE ATIVIDADES PRÁTICAS DURANTE A GRADUAÇÃO

BRASÍLIA

2018 
NATÁLIA MARIANA DIÓGENES SILVA DE ALBUQUERQUE JULIANA TERRA RIBEIRO

ANÁLISE COMPARATIVA SOBRE A PERCEPÇÃO DOS ESTUDANTES DE MEDICINA ACERCA DO IMPACTO DAS DISCIPLINAS IESC E HA NO CONTEXTO DE ATIVIDADES PRÁTICAS DURANTE A GRADUAÇÃO

Relatório final de pesquisa de Iniciação Científica apresentado à Assessoria de Pós-Graduação e Pesquisa.

Orientação: Tania Inessa Martins de Resende

BRASÍLIA

2018 


\title{
ANÁLISE COMPARATIVA SOBRE A PERCEPÇÃO DOS ESTUDANTES DE MEDICINA ACERCA DO IMPACTO DAS DISCIPLINAS IESC E HA NO CONTEXTO DE ATIVIDADES PRÁTICAS DURANTE A GRADUAÇÃO
}

\author{
Natália Mariana Diógenes Silva de Albuquerque \\ natalia.mariana@sempreceub.com
}

Juliana Terra Ribeiro

juliana.terra@sempreceub.com

\section{Tania Inessa Martins de Resende}

tania.resende@ceub.edu.br

\begin{abstract}
Resumo
A metodologia ativa de ensino permite a inserção precoce do estudante de medicina em unidades básicas de saúde, sendo gradual a sua evolução nas práticas médicas. Para que esse processo seja possível o estudante necessita de respaldo conteudista e de orientação quanto aos limites do que lhe é permitido realizar de acordo com o semestre em que se encontra. Assim, dentro da graduação médica no UniCEUB, o estudante é submetido a dois eixos educacionais que tem por objetivo prepara-lo para uma melhor atuação profissional: Interação Ensino Saúde e Comunidade (IESC) e Habilidades e Atitudes profissionais (HA). As disciplinas que compõem o eixo de HA visam desenvolver a semioténica e a semiologia aplicada, incluindo capacidade de raciocínio clínico e técnicas cirúrgicas e aprimorar a qualidade do atendimento dos pacientes. Em contrapartida, no eixo de IESC o aluno desenvolve habilidades de comunicação e fortalece o vínculo com os usuários dos serviços de saúde, de forma que tende a aperfeiçoar, cada vez mais, a relação médico-paciente, por estar envolvido no planejamento de estratégias e implantação de ações de promoção de saúde. Dessa forma, é esperado um sinergismo entre as disciplinas de HA e IESC, de modo que conhecimentos e técnicas adquiridas no eixo de HA tendem a melhorar o desempenho dos alunos nas atividades práticas desenvolvidas em IESC e vice-versa. É importante salientar que em ambos os eixos, desde o primeiro semestre, os graduandos de uma mesma turma são subdivididos em grupos, o que facilita a realização das atividades práticas nos diversos cenários de saúde e melhora a condução dos grupos por parte dos docentes. Para investigar a maneira como tais eixos têm se desenvolvido no UniCEUB e verificar a relação existente entre eles, foi realizada na Instituição uma pesquisa transversal qualitativa com a técnica de grupos focais, com as turmas do terceiro ao oitavo semestre da graduação de medicina. O objetivo dos grupos focais era extrair, na perspectiva do
\end{abstract}


discente, a importância de tais eixos educacionais para a formação médica. Por ser uma pesquisa a partir de um curso em que se emprega a metodologia ativa, o ponto de vista dos alunos no processo educativo é fundamental, de forma que a metodologia que melhor permite ouvir e produzir informações que possam influenciar no processo educativo e avaliativo é a qualitativa. Foi possível, após análise dos grupos focais, a partir da hermenêutica de profundidade, perceber que existem problemas estruturais relacionados aos dois eixos de ensino, principalmente relacionados à maneira como são conduzidos pelo corpo docente. Assim, os discentes consideraram como problemas centrais, de ambos os eixos, a desorganização e a despadronização dos alunos quanto ao conhecimento desenvolvido ao longo dos semestres, o que é evidenciado, em especial, quando se compara os subgrupos de uma mesma turma. Além disso, foi possível concluir que os eixos de IESC e HA, apesar das limitações que possuem na instituição, são considerados fundamentais para a formação de um médico mais humano e que preza pela boa relação com paciente e com o cenário de saúde em que está inserido.

Palavras-Chave: Ensino médico. Escolas médicas. Aprendizagem Baseada em Problemas. IESC. Habilidades. 


\section{Sumário}

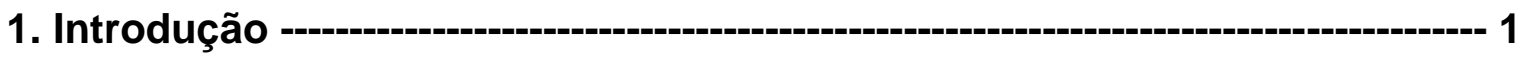

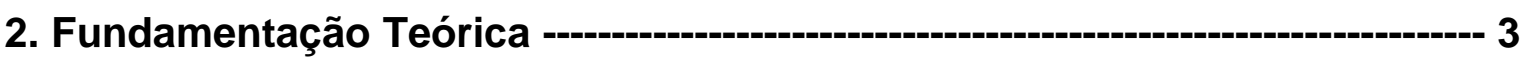

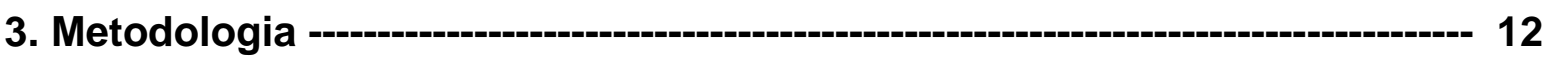

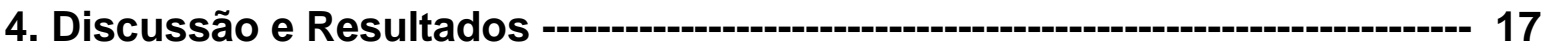

4.1. Análise sócio histórica --- 17

4.2. Análise Formal --

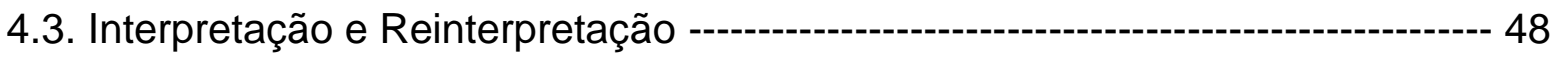

5. Considerações finais ---:-ar

$--61$

APÊNDICE A $-66$

APÊNDICE B $-67$

ANEXO 1 $-69$ 


\section{Introdução}

Atividades práticas nos serviços de saúde têm grande impacto no processo de formação médica. Por meio dessas, o estudante pode se tornar um médico mais humano, crítico e competente na relação médico-paciente. O Projeto Político Pedagógico, a partir de novas Diretrizes Curriculares Nacionais (DCN) em 2001, prevê uma maior articulação entre a teoria e a prática, rompendo com a dicotomia que as separa e proporcionando aprendizagem significativa, capaz de gerar profissionais mais comprometidos e humanizados (CHIRELLI; MISHIMA, 2003).

Esse novo formato de ensino, em que o aluno se torna ativo no processo de aprendizagem, foi possível por meio da implantação de metodologias ativas nas faculdades de medicina no Brasil (BRASIL, 2001). Essas metodologias têm por base uma aprendizagem em espiral, permitindo que os discentes ampliem raciocínio clínico e habilidades profissionais e ética-emocionais no decorrer do curso (TEÓFILO; SANTOS; BADUY, 2017).

Assim, durante o ciclo básico da graduação, correspondente aos dois primeiros anos, o aluno é inserido nos cenários de práticas em saúde, onde passa a compreender, de modo mais efetivo, o conteúdo teórico abordado nas disciplinas de Interação, Ensino, Saúde e Comunidade (IESC) e Habilidades e Atitudes Profissionais (HA), tais como: elaboração de ecomapa, genograma, mapa territorial, Projeto Terapêutico Singular (PTS), realização de Visitas Domiciliares (VD), aferição de sinais vitais e atuação em promoção e prevenção de saúde na população (UniCEUB, 2001).

Durante o ciclo clínico, terceiro e quarto ano da graduação, os alunos atuam ativamente nos serviços de saúde. No eixo educacional de IESC, o discente amplia seu contato com a comunidade, tendo como principal instrumento a VD e o PTS e no eixo de HA os graduandos passam a aplicar a semiotécnica nos atendimentos aos pacientes sob supervisão dos médicos responsáveis (UniCEUB, 2001). A integração entre esses dois eixos nas atividades práticas, ao longo dos quatro primeiros anos, promove crescimento e capacitação adequada para a prática médica futura (TEÓFILO; SANTOS; BADUY, 2017).

Na graduação de medicina no Centro Universitário de Brasília (UniCEUB), o eixo de HA é composto por habilidades clínicas, cirúrgicas e profissionais. Esse eixo 
visa aprimorar a semiotécnica, o raciocínio clínico, as técnicas cirúrgicas e a qualidade na relação médico-paciente, ressaltando a importância da ética médica nas diferentes esferas de atuação (UniCEUB, 2001). Além disso, na VD, atividade realizada no eixo de IESC, os graduandos se tornam responsáveis pelo acompanhamento longitudinal de algumas famílias e devem ser capazes de elaborar um PTS, o qual visa atender as demandas identificadas naqueles domicílios. Ao mesmo tempo, por meio dos debates, entre estudantes, docentes e profissionais de saúde vinculados às famílias, é possível ampliar a visão biopsicossocial daqueles pacientes (TEÓFILO; SANTOS; BADUY, 2017). Koga Júnior et al (2016) apontam o sinergismo entre as disciplinas de HA e IESC, de forma que conhecimentos e técnicas adquiridas no eixo de HA melhoram o desempenho dos alunos nas atividades práticas desenvolvidas em IESC, como, por exemplo, na VD.

Um estudo realizado por Santos et al (2015), entretanto, apontou algumas limitações presentes nas metodologias ativas como: a heterogeneidade na rotina dos grupos de alunos durante as práticas; discentes que atuam predominantemente como observadores nas atividades; a assiduidade dos preceptores, o que compromete o aprendizado e a formação ética dos discentes proposta pelo método de aprendizagem baseada em problemas (ABP).

Diante do exposto, percebeu-se a importância de avaliar, a partir da percepção dos estudantes de medicina do UniCEUB, instituição privada de ensino que adota a metodologia ABP, a relação existente entre os eixos de IESC e HA e o impacto de tais disciplinas na formação acadêmica do graduando. Além disso, buscou-se avaliar, do ponto de vista dos discentes, a percepção do impacto das atividades práticas desenvolvidas na unidade de ensino para a capacitação dos estudantes ao longo da graduação e a evolução dos alunos durante os semestres.

As disciplinas que foram o foco do estudo objetivam, no entanto, desenvolver habilidades distintas nos discentes. Diante disso, passou a ser objeto de análise do estudo, a partir do ponto de vista do aluno, entender como as atividades desenvolvidas no eixo IESC capacitam os estudantes a desenvolverem uma comunicação efetiva com a comunidade do cenário de prática, relacionando às visitas domiciliares e aos atendimentos dos usuários nos Centros de Saúde. Buscouse compreender também se, para os alunos, dentro do eixo de IESC eles desenvolvem habilidades de comunicação que favorecem a relação médico-paciente e a que atribuem o desenvolvimento de tais habilidades. 
Dentro do eixo de HA percebeu-se a necessidade de avaliar a contribuição que as disciplinas de habilidades profissionais e de habilidades clínicas proporcionam para o crescimento acadêmico do aluno. Em profissionalismo um dos focos de análise foi entender se os estudantes conseguem aplicar nas práticas de IESC e HA habilidades como empatia, comunicação, estabelecimento de vínculos médico-paciente, capacidade de escuta ativa. Já em habilidades clínicas averiguouse, a partir da percepção dos discentes, se a semiotécnica aprendida dentro da instituição conseguia, de forma eficaz, ser aplicada pelos alunos durante as atividades práticas de IESC e HA.

Tendo em vista que poderiam surgir vários aspectos contraditórios ao que é preconizado pelas metodologias ativas ou pelo projeto pedagógico institucional, tornou-se fundamental saber, por parte dos discentes, as sugestões que culminariam em um melhor aproveitamento dos eixos educacionais de IESC e HA, refletindo sobre os limites encontrados na implantação dessas disciplinas de metodologia ativa na instituição e as contribuições das mesmas para a capacitação dos estudantes ao longo do curso. Com isso, os discentes de todos os grupos focais propuseram mudanças para que os eixos de IESC e HA sejam melhor aproveitados e mais efetivos para a construção do futuro profissional médico.

$\mathrm{Na}$ fundamentação teórica serão apresentadas reflexões e análises, de diferentes autores, sobre a medicina e seus diferentes métodos de ensino, o ABP e sobre os eixos IESC e HA e a interação dos mesmos. Na metodologia será apresentada a descrição da técnica de grupos focais, bem como as perguntas norteadoras desse trabalho e as técnicas de análise. A seguir serão apresentados os resultados e discussões das informações produzidas a partir da hermenêutica de profundidade (DEMO, 2001). Por fim serão apresentadas propostas para aprimoramento dos eixos IESC e HA no curso de Medicina.

\section{Fundamentação Teórica}

A Constituição Federal de 1988 passou por diversas mudanças, dentre essas a publicação da lei 8080/90 que regulamentou o Sistema Único de Saúde (SUS), de forma que, a partir de então, foram levantados questionamentos acerca da formação dos profissionais de saúde, o que, consequentemente, culminou em alterações significativas na graduação desses profissionais devido às profundas mudanças nas 
práticas de saúde após a criação desse sistema (CAVALHEIRO, GUIMARÃES, 2011).

O artigo 27 da lei 8080/90 ressalta a íntima relação existente entre os campos de atuação dos serviços de saúde oferecidos no SUS e os cenários de atividades práticas de Instituições de Educação Superior (IES), de modo que há uma possibilidade de articular os interesses comuns a essas duas "instituições", o que favorece a qualidade do atendimento à população (CAVALHEIRO, GUIMARÃES, 2011).

Em 2001, o Ministério da Educação e Cultura (MEC), por meio do Conselho Nacional de Saúde/Centro de Ensino Superior, adotou algumas estratégias visando uma mudança no currículo acadêmico, tanto para os cursos de medicina, quanto para os outros cursos na área da saúde, propondo que os discentes estivessem mais inseridos nas atividades práticas durante a graduação. Assim, novas diretrizes curriculares foram estabelecidas, incluindo competências e habilidades, de forma que as faculdades e universidades necessitaram se readaptar a uma nova realidade (BRASIL, 2001).

A resolução CNE/CES № 4, de 7 de novembro de 2001 instituiu Diretrizes Curriculares Nacionais (DCN) no Curso de Graduação em Medicina, em que, o Art. $5^{\circ}$, deixa claro que:

a formação do médico tem por objetivo dotar o profissional dos conhecimentos requeridos para o exercício das seguintes competências e habilidades específicas: I - promover estilos de vida saudáveis, conciliando as necessidades tanto dos seus clientes/pacientes quanto às de sua comunidade, atuando como agente de transformação social; II - atuar nos diferentes níveis de atendimento à saúde, com ênfase nos atendimentos primário e secundário (BRASIL, 2001, p. 2).

O Ministério da Saúde, juntamente com o MEC e outras instituições relacionadas à educação, após discussões e debates durante os anos de 2001 e 2002, propuseram o Projeto de Incentivo a Mudanças Curriculares para os Cursos de Medicina (Promed) que se refere a uma atuação conjunta entre as escolas de graduação em medicina com o cenário do SUS. Nesse sentido, as faculdades e universidades de medicina que se dispusessem a adotar as mudanças curriculares de acordo com as necessidades do SUS estariam integradas ao Promed, refletindo assim a cooperação técnica que é proposta no programa (BRASIL, 2002). As mudanças curriculares que passaram a ser implantados na graduação de medicina em 2001 pareciam ocorrer, no entanto, em uma velocidade inversamente 
proporcional às necessidades da população nos serviços públicos daquela época (OLIVEIRA et al, 2008).

Dentre as mudanças propostas nas novas Diretrizes Curriculares Nacionais (DCN) deve-se ressaltar que a aproximação dos graduandos em medicina com o sistema de saúde e com a sociedade foi uma das principais, e mais significativas, reformas no currículo médico, tendo em vista que a formação acadêmica passou a estar voltada ao modelo de saúde vigente no país (FRANCO; CUBAS; FRANCO, 2014). A partir das novas DCN para os cursos na área da saúde houve uma mudança nas prioridades dos planos de ensino nas escolas de medicina, de modo que a formação do profissional deveria estar amplamente voltada para uma clínica associada a uma responsabilidade social, tendo o futuro médico a necessidade de compreender cada sujeito como um ser único e dentro de um contexto biopsicossocial (GOMES; REGO, 2011).

Esse currículo inovador está intimamente relacionado com as novas metodologias ativas de ensino, as quais vêm substituindo gradativamente o modelo tradicional. Essas novas metodologias passaram a ter destaque dentro das universidades e faculdades de medicina, visando a formação de profissionais humanistas, com capacidade crítica e reflexiva e que esteja capacitado a transformar o que está ao seu alcance dentro da realidade do sistema de saúde (PASQUALINI et al, 2016). Como os cursos na área de ciências da saúde estão diretamente relacionados ao processo saúde-doença do homem 0 desenvolvimento do conhecimento deve ocorrer dentro de um modelo de ensino que seja articulado e integrado, o que vai de encontro com as propostas da metodologia ativa (MELO et al, 2017; ROCHA et al, 2016).

As estratégias de ensino que visam uma aprendizagem mais ativa passaram a enfatizar o desenvolvimento de habilidades, atitudes e conhecimento, formando uma tríade que coloca o aluno como foco principal, de forma a reduzir a quantidade de conteúdos expositivos conceituais e valorizar a busca ativa e individual do conhecimento. Assim, esses novos modelos de ensino preveem uma integração vertical e horizontal das disciplinas, de modo que o conhecimento vai sendo construído ao longo da graduação integrando a aplicação desses conhecimentos nos cenários de prática, os quais correspondem aos diversos níveis de atenção à saúde (SOUZA; IGLESIAS; PAZIN FILHO, 2014). 
Os autores Ceccim e Cabellero (2013) e Lave e Wenger (1991) usam expressões como "comunidade de aprendizagem" e "intervenção social", respectivamente, a fim de analisarem as mudanças do processo de aprendizagem nos cenários de saúde. A primeira expressão, usada por Ceccim e Cabellero (2013), se refere à integração ensino-serviço que possibilita a interação do ensino superior com os diversos cenários de saúde oferecidos à comunidade, favorecendo uma nova percepção do discente e do docente acerca do processo ensino-aprendizagemsaúde. Já a segunda expressão, usada por Lave e Wenger (1991), propõe a ideia de intervenção dentro das comunidades e defende que os atores sociais, como os graduandos, têm a capacidade de se organizar para que possam agir como um grupo social de intervenção e assim criar com a comunidade uma relação de confiança e engajamento mútuo, através de um modelo de aprendizagem baseado na realidade (JUNGES; CECCIM; POSSA; 2017).

A proposta de ensino das metodologias ativas tem como base o cenário de práticas sendo que dentro do ensino ativo utilizadas na formação dos profissionais de saúde, destaca-se a Problematização, que tem como base uma aprendizagem baseada no clássico "ação-reflexão-ação". Nesse método, o discente, inserido em um cenário de prática, observa a realidade e a partir de então determina os principais postos-chave que devem ser estudados de modo crítico-reflexivo, visando uma resolução para os problemas identificados, de forma a tentar transformar aquela realidade que o cerca, com soluções plausíveis e viáveis naquele contexto e que tenham um embasamento científico (XAVIER, et al, 2014).

Cabe destacar que a implantação das metodologias ativas enfrenta resistências decorrentes dos modelos tradicionais outrora prevalentes no processo ensino-aprendizagem. Uma dificuldade enfrentada pelos sistemas educacionais que aderem à nova proposta metodológica é a imposição de conteúdos considerados indispensáveis na graduação, os quais são selecionados como um "conteúdo essencial" e trabalhados exaustivamente. Outras desvantagens estão relacionadas aos docentes, tendo em vista que o preparo, a aplicação e a avaliação das atividades demandam um tempo maior e a para a própria instituição de ensino, a qual tem maiores gastos por necessitar de um corpo docente mais amplo (SOUZA; IGLESIAS; PAZIN FILHO, 2014). Merhy (1999) aponta como desafio central das escolas que adotam a $\mathrm{ABP}$ a preparação do corpo docente que estará inserido nessa nova realidade de ensino. $O$ autor observa que a metodologia ativa, para ser 
bem implantada e eficaz no processo de ensino, necessita de profissionais bem preparados para esse tipo de atuação, que estejam dispostos a pensar o processo ensino-aprendizagem de forma diferente e dinâmica e que possam atender as necessidades do discente sem abandonar os princípios básicos do método, em que o autor principal do conhecimento é o próprio aluno.

Diante disso, vale destacar que na década de 70 a Universidade de Harvard adotou o novo modelo de ensino e percebeu-se, no entanto, após a formação da primeira turma dentro desse modelo de ensino, diversas falhas no processo de aprendizagem. Após receber os resultados do exame National Board a instituição observou que as deficiências de aprendizagem se concentraram, principalmente nas áreas de conhecimento básico como farmacologia e patologia. Esse fato fez com que Harvard retornasse ao modelo tradicional (GOLDHABER, 1973). Nas décadas subsequentes o ABP passou por diversas modificações, porém as mudanças se tornaram mais relevantes com o ensino baseado em comunidade (EBC) proposto pela Universidade Maastricht, na Holanda (OZÓRIO NETO et al, 2011). Em 1985, Harvard volta a adotar a metodologia ativa na instituição seguindo o modelo ABP (AGUIAR, 2011).

A educação em saúde deve priorizar três etapas: processo ensino-serviço, humanização do atendimento e ampliação da prática da integralidade, princípio norteador do SUS. Essas etapas devem se adequar às necessidades da população e ao fortalecimento do funcionamento do Sistema Único de Saúde, uma vez que integram as atividades práticas dos graduandos das escolas de medicina com os serviços de saúde oferecidos nele (HORA et al, 2013). A partir das novas DCN, com o novo padrão curricular voltado para o modelo de saúde vigente, muitas das atividades de práticas curriculares dos cursos de medicina passaram a estar inseridas em novos cenários e a integrar a dinâmica do SUS.

Dentre essas práticas, a visita domiciliar representa uma das principais ações que compõem a atenção primária e tem se tornado uma ferramenta no processo ensino-aprendizagem na graduação médica (ROMANHOLI; CYRINO, 2012). É por meio dessas visitas que os profissionais de saúde podem passar a entender o contexto social da família assistida, dentro das suas particularidades, identificando suas vulnerabilidades dentro de um contexto biológico e social e favorecendo o vínculo entre os profissionais de saúde e a família (KEBIAN; ACIOLI, 2014). Além disso, o acompanhamento efetivo das famílias favorece o controle de doenças 
crônicas prevalentes em algumas comunidades, como hipertensão arterial e diabetes mellitus, pois a atenção continuada favorece a prevenção dos agravos (SILVA et al, 2016).

No eixo educacional de IESC, uma das principais atividades é a visita domiciliar (VD). Ela pode ser classificada, dentro de uma tríade que envolve as dimensões de método, tecnologia e instrumento, à medida que se caracteriza por práticas de promoção de saúde e prevenção de agravos, além de ser um cenário de aprendizagem e investigação de saúde para os profissionais que nela atuam (MOURÃO et al, 2010). Essa prática, desenvolvida no decorrer do curso de medicina, possibilita que os graduandos desenvolvam atendimentos cada vez mais humanizados, por estarem em contato mais íntimo com os pacientes compreendendo a realidade social e econômica da comunidade em que atuam (PEREIRA et al, 2015).

$\mathrm{Na}$ Atenção Básica, onde se desenvolvem as atividades práticas de IESC, o programa de Estratégia de Saúde da Família (ESF) é relevante para determinar a cobertura populacional na qual os estudantes atuarão. Essa cobertura tem como base as condições socioeconômicas e político-administrativas de uma determinada população, aplicando o conceito de territorialização. Dessa forma, se define uma parcela da comunidade que irá compor uma clientela adscrita em uma determinada região, as quais receberão as visitas domiciliares (KEBIAN; ACIOLI, 2014).

Entende-se, portanto, que o atendimento multidisciplinar na atenção básica é fundamental para que a visita domiciliar seja eficaz, de modo ao promover um acompanhamento longitudinal do paciente, visando a continuidade e a integralidade do cuidado para que todas as necessidades identificadas durante as visitas possam ser sanadas com ações resolutivas de uma equipe multiprofissional. Assim, é importante que, dentro das mudanças organizacionais propostas no campo da saúde coletiva, haja uma prioridade na realização de ações sociais e políticas públicas, de forma a propiciar uma melhor qualidade de vida para a população assistida (SANTANA et al, 2015).

A disciplina de IESC possibilita, ainda, que os estudantes ampliem o contato com pesquisas científicas, tendo em vista que a disciplina é embasada na metodologia de problematização, em que os discentes observam a realidade da comunidade e determinam os problemas a serem sanados (ANDRADE et al, 2011). Além disso, os discentes precisam de artigos científicos como base para que façam 
uma intervenção adequada e plausível naquela população, de acordo com a realidade dela. Assim, os estudos desenvolvidos pelos discentes, com um embasamento científico, podem se configurar uma ferramenta para os gestores na reestruturação de alguns serviços (BERBEL, 2011).

A inserção do estudante de medicina na comunidade desde o início da graduação favorece o desenvolvimento de ações éticas e humanistas, o que tem grande impacto na relação médico-paciente. Segundo Andrade et al (2001), a maioria dos discentes, durante as atividades práticas, demonstram atitudes positivas e respeitam os preceitos éticos da medicina, por exemplo, na abordagem de pacientes com baixa escolaridade que podem divergir da escolha terapêutica do médico e na escuta ativa de pacientes poliqueixosos.

As atividades que fazem parte do currículo na graduação médica têm uma relevância no desenvolvimento de habilidades dos alunos, desde as cognitivas e afetivo-emocionais até habilidades psicomotoras específicas que serão fundamentais na prática médica, de forma que essas contribuem para uma formação integral do médico (COLARES et al, 2002). Um desafio enfrentado durante a formação de jovens médicos é a forte competição existente entre os estudantes durante a graduação, a qual representa um obstáculo diário no cotidiano acadêmico por interferir na cooperação entre os grupos de trabalho. Essa competitividade reflete não só no processo ensino-aprendizagem como também na capacidade dos mesmos em desenvolver habilidades para que estejam inseridos, e saibam atuar, em equipes multidisciplinares. A falta de compreensão da necessidade, e importância, do trabalho multiprofissional é o que faz com que esses estudantes tenham uma formação acadêmica enraizada em um processo ideológico tecnicista (FARIA et al, 2018).

Dentro das disciplinas que desenvolvem a parte prática, como no eixo de Habilidades e Atitudes, é fundamental que seja trabalhado a competência comunicadora dos estudantes, de modo que esses saibam observar e escutar ativamente $o$ paciente $e$, consequentemente, sejam capazes de fazer uma intervenção adequada, favorecendo um diagnóstico correto e um tratamento eficaz (SCHREIBE, 2015).

A transição na educação médica exige mais dessas atividades práticas dos discentes desenvolvidas dentro do eixo de HA nas metodologias ativas. Essas aulas passam a exigir das escolas médicas a disponibilidade de materiais adequados para 
o processo de aprendizagem dos discentes, além de professores capacitados para atuarem como supervisores durante as atividades práticas e contribuírem para a consolidação do conhecimento do estudante de medicina (CEZAR et al, 2010).

Dessa forma, é necessária uma infraestrutura adequada capaz de atender às necessidades acadêmicas durante a graduação para que haja uma maior associação do ensino teorizado com a prática, visando a formação de profissionais cada vez mais capacitados (KOGA JUNIOR et al, 2016). Além disso, o professor dentro do processo ensino-aprendizagem deve ser capaz de desenvolver atividades que estimulem e facilitem o desenvolvimento de habilidades e o raciocínio clínico dos graduandos, visando também fortalecer a autonomia dos mesmos (VIEIRA; PINTO, 2015).

As disciplinas de Habilidades e Atitudes Profissionais devem contemplar três principais esferas: Procedimentos médico-cirúrgicos-laboratoriais, Semiologia e Comunicação Social, de forma que esses três eixos podem ser considerados como os pilares que estruturam a disciplina (UniCEUB, 2001). Além disso, o programa educacional do eixo de HA é embasado em discussões de casos clínicos, a partir de textos teóricos e temas levantados durante as atividades práticas de semiologia nos hospitais de ensino (ANDRADE, et al. 2011).

Vale destacar que a ausência ou precariedade das aulas de Habilidades Clínicas e Profissionais refletem negativamente na formação dos alunos, principalmente nas aptidões práticas, as quais interferem no rendimento dos discentes em outras disciplinas, como na disciplina de IESC que exige o domínio de determinadas práticas clínicas para a abordagem e $\mathrm{o}$ atendimento dos pacientes na comunidade ( KOGA JUNIOR et al, 2016).

Incluir as aulas de Habilidades Clínicas no plano pedagógico do curso de medicina favorece a formação de profissionais mais ambientados à prática médica, visto que o estudante durante a graduação passa a se habituar à rotina que futuramente terá que lidar (VONBANK et al, 2015). O ganho de conhecimento e o aproveitamento do aluno é incomparavelmente maior quando o aprendizado se desenvolve na prática, fato que pode ser observado quando se compara alunos passivos, que apenas recebem uma informação teórica pronta como receptores e ouvintes, com alunos ativos que adquirem conhecimento a partir da vivência prática (SCHREIBE, 2015). Além disso, a integração ensino-serviço promove a interação do discente e do docente com os trabalhadores e os gestores dos serviços de saúde, o 
que culmina em melhorias tanto para a comunidade, por meio da ampliação dos serviços de saúde, quanto para o estudante, devido ao ensino multiprofissional (FINKLER; RAMOS, 2011).

Apesar das propostas apresentadas para os eixos de IESC e HA, algumas falhas foram observadas, uma vez que, apesar do curso se desenvolver dentro da metodologia ativa e ter um currículo voltado para práticas na comunidade desde 0 primeiro semestre, percebe-se uma falta de homogeneidade entre os discentes nas atividades, visto que há alunos que não conseguem aplicar a teoria na prática, o que leva a uma discrepância do aprendizado dentro de uma mesma turma (SANTOS et al, 2015). Além disso, ainda que o ABP favoreça a aproximação do corpo docente com os graduandos e priorize um aprendizado centrado nas vivências práticas, por vezes ele pode se apresentar como mera novidade metodológica, permanecendo com foco na doença, no modelo biomédico e fragmentado (TEÓFILO; SANTOS; BADUY, 2017).

Outra limitação, presente nos eixos educacionais em que há atividades práticas, está relacionada a alguns discentes que são passivos durante as práticas nas unidades de saúde, atuando apenas como observador e não sendo inserido de maneira efetiva na equipe de saúde, o que entra em desacordo com a proposta da metodologia sugerida pela nova DCN. Essa "liberdade restrita" de alguns discentes nas atividades compromete o desenvolvimento de habilidades necessárias para o exercício da profissão médica (SANTOS et al, 2015).

É observado, ainda, na atualidade, um declínio na relação médico-paciente, devido a um predomínio de um modelo de saúde tecnicista, fragmentado, hospitalocêntrico e, cada vez mais, subdividido em especialidades, onde há um predomínio da doença em detrimento do paciente (SIMÕES, 2014). Apesar disso, é esperado que os médicos futuros sejam diferenciados, atuando de forma mais humanista, empática e transformadora na sociedade e mantendo suas ações no processo saúde-doença coerentes com a ética médica (ANDRADE et al, 2011).

Cavalheiro e Guimarães (2011) apontam, em seu trabalho, as principais dificuldades enfrentadas na formação dos profissionais na área da saúde, em relação: 1) às ações indutoras para a formação de profissionais; 2) à possibilidade de matriciamento itinerante, ou seja suporte realizado por uma equipe multidisciplinar a uma determinada comunidade; 3) à formação em saúde para trabalho em equipe. Com relação ao primeiro ponto, o principal desafio é a 
necessidade do Sistema de Saúde em compreender que a parceria com uma Universidade aumenta a produção de conhecimento e que deve ser dada mais importância nos debates acerca dos princípios, diretrizes e bases legais do SUS. Além disso, outra limitação relaciona-se com a falta de articulação cotidiana entre as necessidades do serviço de saúde e do ensino, considerando que é necessário criar uma demanda para que as atividades acadêmicas sejam realizadas. Já o desafio relacionado com o segundo ponto, se deve à falta de comunicação adequada entre a UBS e a Instituição de Ensino, ao número insuficiente de médicos de família para atender à demanda criada e à falta de espaço físico para realizar o matriciamento de maneira efetiva. Por fim, em relação ao terceiro ponto, destaca-se a diferença na organização do currículo dos diferentes cursos envolvidos em um mesmo cenário de atividades práticas durante a graduação (CAVALHEIRO e GUIMARÃES, 2011).

Em um estudo desenvolvido por Santos et al (2015) sobre a avaliação dos discentes sobre a interação ensino, serviços e comunidade em equipes de saúde integradas ao programa Mais Médicos na Amazônia, foi observado que a maior parte dos graduandos de medicina que acompanharam médicos inseridos no programa observaram como pontos negativos: não desenvolver quaisquer responsabilidades no atendimento; não poder realizar anamnese, ainda que pudessem realizar exame físico, e não acompanhar as reuniões da equipe de saúde. Os estudantes viram como alguns dos pontos positivos: treinar a comunicação, aprimorar o aprendizado no atendimento da população carente e identificar suas necessidades de aprendizado. $O$ estudo evidenciou ainda a relevância das visitas domiciliares no desenvolvimento de habilidades e na preparação do egresso para o mercado de trabalho atual e evidenciou pontos negativos e positivos propostos pelo programa que não atenderam às novas demandas.

Estimular o estudante a se capacitar para desenvolver determinadas habilidades vai além de ensiná-lo apenas para a prática clínica. Nesse contexto, adquirir tais habilidades envolve também a aquisição de uma visão humanizada e ampliada do paciente, a partir da observação de cada sujeito, considerando seus aspectos individuais no âmbito social, cultural, econômico e psicológico (SIQUEIRA, 1997). Assim, uma das maiores dificuldades do ensino médico é formar profissionais de saúde humanizados, capacitados para aliar à prática clínica os elementos socioeconômicos, culturais e psicológicos de cada sujeito dentro do processo saúdedoença (OLIVEIRA et al, 2008). 


\section{Metodologia}

O presente estudo se desenvolveu a partir de uma pesquisa transversal qualitativa, a qual utilizou a técnica de grupo focal para identificar as percepções de acadêmicos do curso de medicina sobre as competências pedagógicas de dois eixos educacionais: Interação Ensino Saúde e Comunidade (IESC) e Habilidades e Atitudes Profissionais (HA). Por ser uma análise a partir de um curso em que se emprega a metodologia ativa, a percepção dos alunos nos processos educativos e avaliativos é fundamental, de forma que, se esta premissa é verdadeira, a metodologia que melhor permite ouvir e produzir informações que possam influenciar no processo educativo e avaliativo é a qualitativa.

O grupo focal é uma metodologia que passou a ser utilizada a partir da década de 80 em pesquisas avaliativas, tanto no campo da saúde quanto da educação, e tem sido amplamente aplicada por profissionais que buscam desenvolver pesquisas nessas áreas, visando implementar ou avaliar determinados programas (MORGAN, 1998). A aplicabilidade desse recurso metodológico possibilita a aproximação dos pesquisadores a um público-alvo, nesse caso, os graduandos de medicina do UniCEUB, contribuindo assim para ampliar a visibilidade desse grupo analisado dentro da instituição, de modo que estes serão ouvidos ativamente e suas percepções e demandas serão avaliadas (BORGES; SANTOS, 2005).

A técnica desenvolvida na metodologia de grupo focal possibilita analisar a percepção dos integrantes grupais acerca de determinados programas, permitindo assim um levantamento de dados que pôde ser utilizado como base para aprimoramento, mudanças ou inovações nas atividades desenvolvidas dentro do programa avaliado (BORGES; SANTOS, 2005). Os grupos focais se desenvolvem a partir de um planejamento prévio de montagem dos grupos que leva em conta fatores de inclusão e exclusão. (BORGES; SANTOS, 2005 e RESSEL et al ,2008). Após isso ocorre a coleta dos dados, por meio da realização do grupos focais, em que são realizadas perguntas abertas, previamente categorizadas, aos participantes sendo fundamental que o moderador do grupo ofereça um ambiente favorável a exposição de ideias, passe todas as informações necessárias ao grupo, como tempo de duração do mesmo, e conduza o grupo quanto ao que deseja-se saber (GATTI, 
2005). Ao final da coleta de dados é realizada a análise das informações qualitativas produzidas.

No planejamento e montagem do grupo focal, tomando por base trabalhos já realizados com uso de tal técnica, levou-se em consideração os seguintes fatores: 1) tentou-se priorizar, no recrutamento dos participantes, a escolha daqueles que não pertençam a um mesmo ciclo de amizade, além da escolha ser feita independentemente do gênero, faixa etária ou classe social; 2) o local onde foram realizados os grupos focais era neutro, silencioso e acessível aos discentes participantes; 3) a duração média da reunião com o grupo foi de aproximadamente uma hora e meia; 4) usou-se um roteiro para guiar e mediar a entrevista, contendo os temas relevantes aos objetivos da pesquisa, os quais foram investigados e, posteriormente, analisados; 5) havia no grupo focal um moderador e um observador, funções em que as pesquisadoras se revezavam. O primeiro, mediava a reunião, facilitava a integração entre os discentes participantes e favorecia o debate, e o segundo avaliava as expressões não verbais, atitudes e posicionamento dos participantes durante as reuniões grupais e auxiliava o moderador na conclusão do que foi exposto pelos alunos

Como critério de inclusão, foram selecionados alunos devidamente matriculados no curso de medicina, do terceiro ao oitavo semestre (Segundo, Terceiro e Quarto ano de medicina) e que assinaram o Termo de Consentimento Livre e Esclarecido (TCLE) ${ }^{1}$. Como critério de exclusão, foram afastados do estudo dois grupos de alunos: os discentes que estavam cursando os dois primeiros semestres da graduação médica (Primeiro ano) e os que estavam nos dois últimos anos da graduação (Internato), bem como, aqueles que não estavam regularmente matriculados na instituição e/ou não concordaram com o TCLE. O primeiro grupo foi afastado da coleta de dados por não realizar ainda as visitas domiciliares no cenário de prática e serem passivos frente às atividades desenvolvidas nas Unidades de Saúde e, por isso, não conseguiriam passar o feedback acerca da aplicabilidade das atividades desenvolvidas nos eixos de IESC e HA. O segundo grupo foi excluído do estudo por não ter os eixos educacionais de IESC e HA compondo a grade curricular.

\footnotetext{
${ }^{1}$ ANEXO A
} 
O estudo foi realizado no curso de medicina do Centro Universitário de Brasília (UniCEUB). Cada grupo focal foi destinado a um semestre a ser avaliado (terceiro ao oitavo semestre) para que houvesse um levantamento de dados para uma posterior comparação do efeito das disciplinas de IESC e HA ao longo da graduação. Cada grupo focal foi composto por uma amostra de no mínimo 6 alunos. Foram realizados um total de 7 grupos focais compostos pelos 6 grupos focais (para os 6 semestres avaliados individualmente) e por um último, e único, grupo focal com um representante de cada semestre avaliado individualmente. O último grupo focal teve como ênfase sugestões para melhor aproveitamento dos eixos educacionais de IESC e HA.

Koga Júnior et al(2016) desenvolveram um estudo qualitativo acerca das percepções de estudantes de medicina sobre competências pedagógicas no ABP da Universidade da Amazônia, por meio da utilização de grupos focais. Para aplicação do método o autor seguiu 3 categorias de perguntas semelhantes: Perguntas de abertura, perguntas de desenvolvimento temático e pergunta finalizadora, as quais eram pertinentes para alcançar os objetivos elucidados nesta pesquisa, e, por isso, foram adaptadas para o levantamento de dados no presente estudo. A tabela com as perguntas norteadoras, subdividida nas 3 categorias, pode ser encontrada no apêndice $B$.

Os grupos focais foram realizados somente após submissão e aprovação do trabalho pelo comitê de ética e pesquisa (CEP), o qual ocorreu no mês de setembro de 2017, sendo o número do comprovante 111613/2017 e o número do certificado de aprovação (CAAE) 77175417.0.0000.0023. Todos os grupos focais foram gravados e posteriormente transcritos e analisados.

Todos os discentes participantes dos grupos focais assinaram o Termo de Consentimento Livre e Esclarecido (TCLE) após serem informados sobre a desistência, que poderia ocorrer a qualquer momento, o sigilo, o anonimato e a privacidade das informações, além da disposição dos pesquisadores para esclarecer quaisquer dúvidas que surgissem no decorrer do projeto. Além disso, os discentes participantes receberam esclarecimentos quanto à finalidade da pesquisa desenvolvida e foram informados sobre as características da participação nas atividades, que é livre e voluntária. Vale ressaltar que o projeto não traz qualquer risco ou prejuízo para os envolvidos e que os ganhos baseiam-se apenas a nível educacional e institucional. 
A análise dos dados foi feita a partir da Hermenêutica de Profundidade (HP), cujo o método de análise é uma prática usual em pesquisas em Sociologia e Medicina (SOUZA, 2016). A HP é uma proposta de análise de dados especialmente adequada para estudos sobre fenômenos humanos e sociais complexos, cujo campo-objeto é constituído por sujeitos (THOMPSON, 1995) que vivenciam e interpretam a realidade de modo não-linear e com certa complexidade. Uma vantagem desta metodologia de análise de dados é que esta prevê a standpoint epistomology (THOMPSON, 1995), ou seja, a consideração do ponto de vista, além dos pesquisadores, dos sujeitos pesquisados (no nosso caso, os discentes de medicina do terceiro ao oitavo semestre do UniCEUB).

A Hermenêutica de Profundidade busca colocar o pesquisador, não apenas como um descritor das ideias dos sujeitos, mas como autor de uma nova ideia, ou seja, desenvolvendo uma produção inovadora a partir de um referencial teórico que fundamente o conhecimento. Esse método propicia um aprofundamento no contexto fenomenológico e visa não negligenciar as interações sociais que constituem o campo investigado (VERONESE; GUARESCHI,2006).

A análise a partir da HP prevê três fases complementares: contextualização sócio histórica, análise formal e re-interpretação: 1) Fase de análise sócio histórica: procura colocar em xeque aspectos de tempo e espaço, de modo a considerar fatores como classe, etnia, gênero, entre outros, que constituem uma estrutura social, além de permitir identificar relações de assimetria e desigualdade dentro desse mesmo contexto; 2) Fase de análise formal: avalia as expressões e relações do meio social, considerando expressões verbais e não verbais, que permitem uma avaliação das formas simbólicas desenvolvidas em um determinado contexto; 3) Fase de reinterpretação: primeiramente a interpretação relaciona-se com uma compreensão ampliada do contexto social a ser avaliado, a partir de uma análise formal e crítica, seguida de uma reinterpretação, onde há uma síntese e a criação de novos saberes, novas conclusões e novas perspectivas acerca do contexto avaliado, a partir de uma fundamentação teórica fundamentada, interpretada e plausível (VERONESE, GUARESCHI, 2006).

A análise de fatores sócio-culturais é o primeiro estágio dentro da análise da HP. Essa análise envolve produção, circulação e recepção dos fatores simbólicos em um dado contexto, se tornando, dessa forma, uma fase essencial para a interpretação dos dados. A análise permite concluir que os fenômenos sociais 
nascem de um contexto e circulam dentro de condições sociais, culturais e históricas específicas, as quais são potencialmente reconstruídas a partir de métodos empíricos, observacionais e documentários (THOMPSHON,1995). Tendo como base os trabalhos de Paul Ricoeur, o autor considera que a metodologia desenvolvida na Hermenêutica de Profundidade proporciona tanto uma compreensão filosófica da realidade, quanto uma avaliação das situações sociais. Essa ferramenta, combinada com outras análises metodológicas complementares, explanatórias ou objetivantes, pode ampliar a compreensão dos resultados, fazendo com que estes sejam mais proveitosos (VERONESE; GUARESCHI, 2006).

\section{Discussão e Resultados}

Após a realização dos grupos focais com os estudantes de medicina do UniCEUB, realizados na própria instituição, com alunos da segunda à sétima turma, os áudios gravados, após o consentimento dos participantes, foram transcritos e posteriormente os dados foram analisados.

As pesquisadoras avaliaram cada grupo focal, separadamente, agrupando os dados a partir de três aspectos principais: limitações e desafios da metodologia ativa em si, da aplicação do ABP no UniCEUB e dos eixos de IESC e HA; potencialidades alcançadas pela instituição, pelos docentes e pelos discentes em cada um dos eixos e dentro da metodologia ativa; e propostas sugeridas pelos discentes para a melhoria dos problemas levantados durante os debates.

A análise foi embasada nos três principais pontos citados acima e de forma individual para os eixos educacionais de IESC e HA, que desenvolvem atividades práticas durante a graduação médica, seguindo os objetivos propostos no presente estudo.

A seguir, será apresentada a análise das informações qualitativas produzida durante o primeiro semestre de 2018, seguindo a metodologia da Hermenêutica de Profundidade criada por Thompson (1995) e reinterpretada por Demo (2001), o qual propõe em sua obra uma metodologia para uma contrução analítica, reflexiva e aprofundada das informções qualitativas.

\section{1. ANÁLISE SÓCIO-HISTÓRICA}


A análise sócio-histórica representa a primeira fase de análise da Hermenêutica de Profundidade (HP), método de análise adotado no presente estudo. A HP propicia um aprofundamento no contexto fenomenológico e visa não negligenciar as interações sociais que constituem o campo investigado (VERONESE; GUARESCHI, 2006). A análise sócio histórica é essencial para a avaliação das informações qualitativas produzidas no presente estudo, pois esta etapa consiste na capacidade de reconstrução de condições sociais de produção e circulação das formas simbólicas, as quais não surgem em um vácuo (THOMPSON, 1995; VERONESE; CUARESCHI, 2006).

No mundo atual a circulação de formas simbólicas é algo real e crescente e desempenha um papel fundamental em todas as sociedades, tendo em vista que a troca dessas formas simbólicas, seja através da linguagem ou gestos, por exemplo, estão e são onipresentes na vida social (THOMPSHON,1995). Essa etapa, segundo Thompson (1995), está diretamente relacionada a uma reconstrução do modo como cada sujeito percebe a realidade ao seu redor, considerando suas crenças e opiniões individuais. Dessa forma, interpretar a doxa ${ }^{2}$ é a etapa inicial para desenvolver a análise da Hermenêutica de Profundidade, não se limitando apenas à constatação e à descrição para que seja realizado um trabalho reflexivo aprofundado (VERONESE; GUARESCHI, 2006).

O campo de estudo de uma pesquisa sócio-histórica leva em consideração não só a congruência entre os objetos, acontecimentos e ações observadas e analisadas, como também a subjetividade construída a partir de sujeitos que estão em busca de interpretar expressões e ações significativas produzidas por terceiros. Dessa forma, o objeto-domínio da pesquisa é construído sob a perspectiva de processos de compreensão-interpretação relacionados à vida cotidiana. O objetivo da pesquisa sócio histórica é compreender determinados fenômenos significativos muitas vezes já compreendidos, em partes, por sujeitos que compõem uma determinada sociedade analisada, ou seja, reinterpretar um domínio pré-interpretado (THOMPSHON,1995). Nesse sentido, o presente estudo avalia o ABP aplicado no UniCEUB e os eixos de IESC e HA da instituição a partir da compreensão do

\footnotetext{
2 Doxa, para Thompson, é a interpretação do sujeito com relação ao seu cotidiano, a maneira como a pessoa percebe a realidade ao seu redor, suas opiniões, crenças e compreensões.
} 
discente de medicina, o sujeito, na faculdade de medicina da instituição, a sociedade analisada.

O UniCEUB tornou-se o primeiro centro universitário da Distrito Federal (DF) na década de 90, onde passou a se chamar Centro Universitário de Brasília (UniCEUB). A instituição oferece atualmente cursos nas áreas de ciências jurídicas, ciências sociais, ciências exatas, ciências da saúde, ciências da educação e tecnologia, além dos cursos de pós-graduação lato e stricto sensu ${ }^{3}$. A instituição tem dentre as suas propostas de ensino uma política de renovação permanente, de forma que tem buscado acompanhar tanto as evoluções tecnológicas, quanto pedagógicas. O curso de medicina, fundado em 2013, é o único na instituição que se desenvolve a partir da Metodologia Ativa de Aprendizagem, seguindo, dessa forma, as novas diretrizes curriculares nacionais (DCN). Dentre as mudanças propostas nas novas DCN, deve-se destacar a aproximação dos graduandos de medicina com o sistema de saúde e com a sociedade, a qual favorece uma formação acadêmica que passa a estar voltada ao modelo de saúde vigente no país (FRANCO; CUBA; FRANCO, 2014).

O UniCEUB propõe que o aluno seja, desde o início da graduação, inserido em atividades essenciais à prática médica com grau de complexidade progressivo e será, constantemente, acompanhado em relação ao seu desenvolvimento, desde a sua capacidade cognitiva até suas habilidades médicas. O ensino no UniCEUB propõe a formação de médicos com um olhar integral e humanizado voltado para o modo de viver de cada indivíduo, família e comunidade. Isto ocorre mediante as atividades na graduação que se desenvolvem no campo prático desde o primeiro semestre do curso (UniCEUB, 2001).

O curso de medicina do UniCEUB é atualmente composto por aproximadamente 500 estudantes,10 turmas, com média de 20 a 25 anos de idade, e se desenvolve sob a perspectiva da metodologia de Aprendizagem Baseada em Problemas (ABP) também denominado Problem Based Learning (PBL). O ABP possui muitas características, sendo uma delas a construção do conhecimento, grupal ou individual, guiada pelo docente e estruturada em problemas que podem ocorrer fora de sala de aula. A partir disso, o aluno pode ir para campo e relacionar teoria e prática o que resulta em uma formação contextualizada e que colabora para

\footnotetext{
${ }^{3}$ Informações retiradas do site do UniCEUB: https://www.uniceub.br/
} 
compreensão e enfrentamento do processo saúde-doença (ROMANHOLI; CYRINO, 2012). Nesse modelo, o discente torna-se o agente ativo no processo de aprendizado e o professor torna-se o agente facilitador do conhecimento, sendo que este desempenha variadas funções de acordo com a disciplina pelo qual é responsável, podendo estar no papel de tutor, consultor, preceptor clínico, orientador, preceptor de laboratório, coordenador de turma e pesquisador (GONÇALVES; PEREIRA 2009). Assim, discente e docente necessitam um do outro para que haja uma verdadeira construção de conhecimento.

A aplicação de novo modelo de ensino implica por si só em diversos desafios. A instituição necessita de um espaço físico adequado, de oferta de materiais didáticos, de um corpo docente bem preparado, todos esses requisitos implicam em uma maior disponibilidade de recursos financeiros. Além disso, e dessa forma assumindo o desafio central na implantação do ABP, a instituição e o corpo docente necessitam repensar o modelo ensino-aprendizagem para que assim possam efetivamente implementar mudanças que auxiliem os discentes a assumirem um papel ativo em sua aprendizagem. A modificação da transmissão do conhecimento exige treino dos profissionais e que os mesmos conheçam a fundo a proposta da nova metodologia, caso contrário o corpo docente pode tornar-se apenas agente passivo no cenário de ensino-aprendizagem. Como salienta Merhy (1999, p.13 ):

\footnotetext{
Imaginemos, primeiramente, uma escola que tenha situações estruturais adequadas para realizar seus projetos de formação, ou seja, esta escola conta com área física, docentes, dinheiro, serviços, etc..., em número suficiente para construir bons indicadores sobre disponibilidade de recursos. Nem por isso, o ensino será adequado ou, nem por isso, o perfil do profissional que formará será "novo". A nossa imaginação tem que ir além dos recursos estruturais e pensar sobre os modos como os dispomos para "produzir" os nossos médicos. Precisamos olhar para o modo como governamos os processos de ensino-aprendizagem e todas as variáveis que implicam na sua composição, como, por exemplo, as maneiras como os docentes se vinculam as práticas de ensino, suas adesões às necessidades dos alunos, os seus modos de agirem na produção dos serviços, entre outros.
}

Tais desafios podem ser potencializados no UniCEUB tendo em vista que a instituição, até então, não possuía nenhum outro curso no formato ABP e ainda não possui nenhuma turma de medicina formada, o que dificulta a percepção do que realmente é ou não fundamental para a formação acadêmica dos futuros médicos. $O$ que foi observado na instituição pelos discentes, por meio dos resultados que serão apresentados a seguir, é que a instituição atende boa parte do que é esperado no que tange à infraestrutura e recursos didáticos, porém, é necessário um melhor 
treinamento dos profissionais que compõem o corpo docente nos diversos cenários de ensino. Além disso, os discentes pontuam que, por vezes, suas críticas e sugestões não são "ouvidas" pela coordenação do curso.

Nesse sentido o fenômeno a ser avaliado será a impressão do estudante de medicina do UniCEUB acerca da relevância de dois eixos educacionais que integram teoria e prática, IESC e HA. O discente é o sujeito que compõe a sociedade acadêmica em análise e o UniCEUB é o cenário que promove a realidade a ser analisada. Assim, há uma tentativa no presente estudo em compreender como o aluno de medicina do UniCEUB enxerga sua realidade acadêmica e o que acredita que seria possível mudar para que o processo de aprendizagem durante a graduação seja melhor aproveitado e mais efetivo. Ao mesmo tempo, torna-se evidente a importância em entender os papeis de cada um, da instituição de ensino e do corpo docente dentro desse contexto, uma vez que a ABP necessita de uma harmonia entre diversos fatores, como infraestrutura e profissionais atuantes, para garantir que o processo ensino-aprendizagem se dê de forma satisfatória.

\section{2. ANÁLISE FORMAL}

Nesta etapa do trabalho será apresentada a análise qualitativa dos resultados, de acordo com os três principais aspectos avaliados, separadamente, nos sete grupos focais realizados: Potencialidades alcançadas, Limitações e desafios, e Propostas e sugestões.

Haverá subdivisões dentro de cada uma das três dimensões analisadas, para que haja melhor avaliação, por parte dos discentes e das pesquisadoras, do modelo de ensino ABP aplicado no UniCEUB, dos dois eixos educacionais de IESC e de HA e, por fim, do sinergismo entre tais eixos.

Os grupos focais (GF) foram realizados no UniCEUB de acordo com a disponibilidade dos participantes. Cada GF foi avaliado de forma individual e em dias diferentes. Para formação de cada grupo obedeceu-se a regra pré-estabelecida de serem no mínimo 6 alunos compondo o grupo. O GF final, o qual deveria contar com a presença de um membro de cada turma previamente avaliada, não contou com a 
presença de um representante de uma das turmas, mas ainda assim foi composto por 6 alunos. ${ }^{4}$

A análise foi realizada após levantamento de dados extraídos das transcrições as quais sucederam as gravações de áudio dos GF via celular e notebook. A análise das transcrições ocorreu em duas etapas: primeiramente foi analisada as particularidades de cada grupo e em um segundo momento agrupandose o que foi dito de forma semelhante, e também discrepante, entre os grupos focais.

Os GF serão referenciados durante a discussão e nomeados de acordo com a ordem em que foram realizados, sendo o grupo 1 o primeiro grupo a ser avaliado, 0 grupo dois o segundo e assim sucessivamente (Tabela 2). O GF, composto por alunos de diferentes turmas e que participaram previamente dos grupos focais, será definido como grupo final. O grupo final teve como foco principal suscitar propostas para todas, ou para maior parte, das limitações apontadas. Salientamos que como o eixo de tutorial apareceu espontaneamente ao longo de todas as discussões dos GF e em todos os grupos seus dados também serão apresentados, apesar desse eixo não fazer parte, inicialmente, dos objetivos do trabalho.

Foram elaboradas três tabelas para melhor compreensão das descrições realizadas pelos GF, as quais poderão ser encontradas no apêndice B. A tabela 2 é referente aos GF e as ordens de realização de cada um, a tabela 3 apresenta os temas referentes a cada semestre de IESC e a tabela 4 discorrerá o que é desenvolvido, de acordo com ano e ciclo da faculdade, dentro do eixo de HA.

\subsubsection{Potencialidades alcançadas}

\subsubsection{Metodologia Ativa e o ABP no UniCEUB:}

Entre os grupos focais (GF) realizados foi praticamente unanimidade, entre todos os alunos, a compreensão de que a metodologia ativa (MA) é uma excelente estratégia de ensino (se achar que excelente é um termo muito forte podem modificar; minha intenção aqui foi apenas utilizar uma linguagem um pouco mais formal). Vários foram os adjetivos que qualificaram o método, sendo que os grupos 2

\footnotetext{
${ }^{4} \mathrm{O}$ convite foi reiterado aos alunos da turma que participaram do GF, porém, eles não se interessaram em participar do GF final.
} 
e 4 acreditam que seja uma metodologia superior e o grupo 3 que seja excelente. Para os alunos do grupo 1, o ABP auxilia no desenvolvimento de habilidades para pesquisa, uma vez que é imposto ao aluno a necessidade de que ele seja construtor do seu próprio conhecimento. Segundo o Grupo 1, p. 3:

\begin{abstract}
"Hoje em dia o conhecimento é muito acessível e o aluno não precisa mais ficar atrás do professor para passar o conteúdo pra ele, ele tem o conteúdo acessível.." "... para meu estilo de estudo faz muito bem, eu ter que, apesar da responsabilidade, ir atrás de uma fonte, depois estudá-la e apresentá-la para os colegas e tutores observando, é um método efetivo se comparado ao que eu vivenciava no ensino médio".
\end{abstract}

Todos os alunos concordaram que a metodologia ativa retira o estudante da zona de conforto e o condiciona a desenvolver habilidades essenciais para o crescimento acadêmico e profissional, tais como: estudar diariamente devido às cobranças constantes e avaliações contínuas; ser ativo na busca do conhecimento; questionar o conteúdo que lhe é transmitido. Tais habilidades foram citadas por todos e detalhadas pelo grupo 1. Os alunos expuseram ainda que a metodologia permite que o mesmo assunto seja estudado mais de uma vez ao longo de cada ciclo, ciclo básico e ciclo clínico, e em diferentes graus de profundidade o que favorece a construção do raciocínio clínico e a sedimentação do conhecimento. "Na metodologia ativa os conteúdos estão entrelaçados..” (Grupo 1). "O aluno tem capacidade de discutir com o tutor e com quem seja..." (Grupo final).

A ideia sobre a metodologia ativa que foi exposta pelo grupo 1, e que foi contemplada de diferentes maneiras em todos GF, está em acordo com o proposto por Souza e Dourado (2015, p.198)

\begin{abstract}
Assim, trabalhar com problemas reais, por meio do $\mathrm{PBL}^{5}$, supõe deixar de lado, a ideia de que aprender significa memorizar conceitos transmitidos de manuais didáticos. Consiste, sim, em processar as informações adquiridas por meio da pesquisa, acrescentando novas compreensões significativas, para a ampliação do conhecimento investigado.
\end{abstract}

Ainda dentro da discussão sobre a MA os alunos do grupo 3 pontuaram a desconstrução do papel tradicional do professor que no método ativo passa a ser mais um veículo de acesso de conhecimento e não o único dententor do conhecimento. Nesse ponto o discente entende que passa a "desendeusar" o docente. A mesma ideia foi exposta no grupo final e nos grupos 1 e 5 . "Você desendeusa. Você tira aquele brilho todo de um super profissional, professor, que tem todo conhecimento. Então, você passar a compartilhar as coisas que você também viu e acaba até atualizando os tutores” (Grupo 3).

\footnotetext{
${ }^{5}$ PBL, do inglês, significa Problem Based Learning, que representa a Aprendizagem Baseada em Problemas (ABP)
} 
Quando os alunos foram questionados sobre a aplicação da MA no UniCEUB houve uma divergência de opiniões, sendo que, apenas para alguns alunos do grupo 4 o método é bem aplicado na instituição e a maioria dos docentes são capacitados. Os discentes dos demais grupos acreditam que o método não tem sido bem desenvolvido na instituição. Os grupos 3 e 4 avaliaram que no UniCEUB a maioria dos professores tem o interesse em formar médicos mais humanos, que saibam ouvir o paciente e que olhem para o indivíduo de maneira integral, ideia que se coaduna com um dos princípios proposto na ABP, como explicitado por Finkler e Ramos (2011) e por Junges, Ceccim e possa (2017).

Os discentes dos grupos 1, 2, 3, 5 e grupo final apontaram que uma das vantagens do método é que o aluno aprende a buscar o próprio conhecimento e acaba estudando mais por não ter a possibilidade de ficar à espera do conhecimento por meio de aulas tradicionais. Esse novo estilo de construção do saber, segundo alunos dos grupos 2, 3, 5, 6 e grupo final, permite que o docente deixa de ser o detentor absoluto do conhecimento: fator que colabora, em suas percepções, para discussões mais ricas e com maior compartilhamento de conhecimentos por parte do aluno.

O eixo tutorial, o terceiro eixo de ensino que compõe a fundamentação do ABP na medicina e estrutura o curso (UniCEUB, 2001), também se tornou espontaneamente foco de discussão dos alunos ao longo das discussões realizadas, apesar de não fazer parte dos objetivos pré-estabelecidos do trabalho e não estar explicitado nas perguntas direcionadoras. Os alunos dos grupos 1,4 e grupo final expuseram que o eixo tutorial é o único que consegue, de fato, aplicar a MA no formato ABP, de maneira eficiente dentro da instituição de ensino UniCEUB.

Barros (2006) fala em seu trabalho que nas escolas de medicina, a metodologia proposta pela ABP pode ser considerada uma ação de contracultura, tendo em vista que é um método de aprendizagem que busca entender e investigar os princípios e os processos de um determinado tema estudado, como nas discussões dos grupos tutoriais, e, dessa forma, acaba por desenvolver nos alunos um interesse à pesquisa e à busca ativa pelo conhecimento. A cooperação entre os alunos durante uma tutoria, o papel do tutor, o estudo auto assistido, o aprendizado multidisciplinar e as avaliações continuadas são, em conjunto, ações fundamentais para que a metodologia seja colocada em prática e seja eficaz. 


\subsubsection{IESC:}

Foi unanimidade entre os grupos o fato de IESC ser o primeiro contato do aluno com paciente. Os grupos 1, 2, 3, 6 e final consideraram que a disciplina possibilita um contato maior dos estudantes com diferentes realidades sociais, econômicas e de faixa etária e com profissionais de saúde, o que permite conhecer na prática as dificuldades enfrentadas na rede de saúde. Além disso, para os alunos dos grupos 3 e final, a disciplina favorece o entendimento sobre o funcionamento do SUS e os serviços oferecidos à população, compreendendo como cada usuário pode e deve ser referenciado dentro da rede de saúde, garantindo a continuidade do cuidado para cada paciente. Essa ideia, no entanto, foi exposta de forma oposta pelo grupo 5 e 6 que acreditam que a disciplina não viabilizou que conhecessem 0 funcionamento do SUS e os serviços da rede de saúde disponíveis para população.

De acordo com o projeto pedagógico do UniCEUB (2001) o objetivo central do eixo é deixar o discente desde o início do curso em contato com a comunidade, de modo que conheça as rotinas e a dinâmica nas Unidades Básicas de Saúde (UBS) e compreenda como se desenvolvem os serviços de Estratégia de Saúde da Família (ESF) no atendimento à população.

Observa-se, então, que de maneira geral, na percepção dos alunos, o objetivo central tem sido contemplado, ao longo dos semestres pela maioria das turmas analisadas.

As ações de saúde realizadas para a comunidade, como as que aconteceram nos CS, na escola, na Instituição de Longa Permanência para idosos (ILPI), por exemplo, foram consideradas pelos grupos 1, 2, 3, 4, 5 e final extremante proveitosas, pois os alunos puderam desenvolvê-las e aplicá-las, fortalecendo tanto o vínculo com a comunidade, quanto às ações de promoção de saúde. Por outro lado, os alunos dos grupos 1, 2 e 3 consideram que as atividades práticas desenvolvidas no Centro de Saúde junto à comunidade representam as ações propostas pelo eixo de IESC.

Para todos os grupos focais, IESC representa a possibilidade do discente aplicar os conhecimentos adquiridos no eixo de habilidades na prática. Para os alunos aplicar as semiotécnicas discutidas em HA na comunidade é uma maneira de aprender e desenvolver a investigação de doenças e ao mesmo tempo de realizar o acompanhamento das doenças crônicas. Apesar dessa ideia ser um consenso entre 
todos os GF, essa realidade não se aplicou aos grupos 2 e 5 que durante vários semestres foram instruídos por um docente a não realizar exames físicos durante as VD. "IESC não é prática de HA" (Grupo 5). No entanto, na seção de IESC do projeto pedagógico, subitem 5 do item 6 , uma das ações previstas nas atividades de IESC corresponde à avaliação dos sinais vitais e exame físico geral e específico (UniCEUB,2001).

Com relação à VD os alunos dos grupos 3 e 5 acreditam serem resolutivos quando as atividades práticas são voltadas para promoção de saúde e prevenção de agravos, principalmente quando a família acompanhada está disposta a aderir às propostas-mudanças sugeridas pelos alunos. Além disso, quando o supervisor, profissional de saúde, está vinculado ao cenário de atuação, o agendamento de consultas e exames torna-se viável e a VD traz melhores resultados, tanto para os alunos quanto para a própria família, ideia expressa também pelos grupos 1 e 4 . A VD com a mesma família, durante três anos consecutivos, permite que os alunos criem um vínculo e desenvolvam habilidades, como empatia, escuta ativa e paciência, o que enriquece a relação médico-paciente. “...Se for olhar como a minha família melhorou por causa dessas coisas que a gente fez em IESC, com certeza. De ouvir o paciente, ter paciência, desenvolver empatia, isso me fez crescer...a gente criou vínculo com a família e acho que isso foi importante" (GRUPO 2). Os alunos do grupo 5 apontaram a ação de uma das docentes, durante a VD no quarto semestre, como sendo algo fundamental para resolução de alguns problemas no núcleo familiar e para intervenção mais construtiva. "A intervenção dela foi boa pra ajudar" (Grupo 5).

Os trabalhos de Mourão (2010), Silva et al (2016) e de Pereira (2015), discutidos previamente na fundamentação teórica, apresentam ideias condizentes com o que foi exposto pelos discentes. Os primeiros autores destacam que a VD é fundamental no processo de promoção de saúde e prevenção de agravos, uma vez que é nesse momento que o paciente tem a oportunidade de tirar suas dúvidas e para os profissionais é o momento em que podem ser identificados fatores de adesão e de abandono do tratamento. O segundo autor evidencia que essas atividades desenvolvidas no decorrer do curso possibilitam que os graduandos desenvolvam atendimentos cada vez mais humanos, uma vez que se encontram em contato direto com diferentes realidades sociais e econômicas. Nesse sentido podemos observar que tanto por meio das atividades realizadas na comunidade 
quanto por meio das VD os alunos têm estado em maior contato com a comunidade e tem conseguido desenvolver habilidades como empatia, confiança, escuta ativa, fundamentais ao bom vínculo médico-paciente.

As problematizações que ocorrem após cada VD, para os grupos 1 e 2, os debates em sala de aula com o docente e a turma, que começaram a ocorrer no sexto semestre, possibilitaram uma melhor visualização do contexto de cada família assistida, colaborando para o levantamento de problemas específicos e a elaboração de intervenções mais efetivas. Para o grupo, os relatórios feitos em cada atividade prática permitem um aprofundamento teórico acerca do tema proposto. "Você tem dúvida sobre alguma coisa, sobre alguma política, você procura, você fundamenta seu relatório, e quando você faz isso, é um aprendizado" (Grupo 1). Os alunos do grupo 2 expuseram que, durante o quinto semestre, tiveram uma problematização sobre o atendimento do paciente psiquiátrico na atenção básica e o processo de estudo teórico, discussão e análise das condutas dos profissionais foi extremamente enriquecedor. "Eu e meu colega acompanhamos esse caso psiquiátrico e vimos algumas condutas erradas, fomos e discutimos isso no CEUB” (Grupo 2). As ideias expostas pelos alunos acerca da problematização e dos seus benefícios são condizentes com o exposto na fundamentação por Xavier et al (2014) que diz que a problematização favorece o estudo critico reflexivo baseado em ação-reflexão-ação.

Para os alunos do grupo 1, 2, 3 e 4, IESC V foi muito produtivo devido à organização implantada para a realização das atividades, além disso, os alunos reconhecem as atividades com os adolescentes desse semestre como sendo de grande importância para comunidade. Os discentes discutiam o assunto, planejavam as ações e depois aplicavam as atividades, sempre respeitando os objetivos a serem alcançados. O IESC III foi definido como IESC perfeito pelos grupos 1, 2, 3, 4 e grupo final. Para o grupo 4, o IESC VI foi o mais proveitoso, o que foi diretamente influenciado pela professora que os acompanhou no sexto semestre, pois a mesma estimulava os debates acerca do tema proposto. Para o grupo 2, o IESC $\vee$ foi o que teve a melhor avaliação conteudista quando comparado aos demais, tendo em vista que a prova foi feita a partir de casos clínicos que integravam de forma eficientemente o conteúdo teórico, discutido nos TBL's, as discussões em sala de aula e a prática. Os alunos referenciaram a prova do quinto semestre como sendo a 
prova "ideal" de IESC. "É pra você discutir o assunto, não é uma resposta certa ou errada, é uma discussão do que você estudou!” (Grupo 2).

$O$ anseio, evidenciado pelos alunos, em ter um cronograma de atividades que seja seguido pode ser justificado pela ideia presente no trabalho de Zuljan (2012) em que se debate a importância da organização do docentes nas atividades do método de ensino ABP, bem como a necessidade de seguir um cronograma de forma a facilitar o processo de aprendizagem dos alunos. No artigo Adolescência e a fomação do profissional de medicina é possível observar a importância e os desafios de se trabalhar o tema adolescência na graduação medica, foco do IESC V. Importante pois os adolescentes não estão nos CS e assim cabe aos profissionais irem até eles para realizar promoção de saúde e prevenção de agravos, medida executada com excelência quando se promove ações na escola. Desafiadora quando se considera que muitos dos discentes estão saindo da adolescência, ou saíram recentemente dela e, portanto, enfrentam conflitos similares aos do público alvo (SILVA; MAGALHÃES; RESENDE, 2018). Nesse sentido torna-se notável o trabalho das três docentes no eixo de IESC $V$ junto aos discentes. ${ }^{6}$

Os discentes dos grupos 1 e 2 consideram o novo método adotado pelo eixo de IESC, o TBL, uma boa proposta, porém questionam a forma como tem sido implantada na instituição. O novo modelo será discutido em outra sessão.

\subsubsection{HABILIDADES:}

Todos os grupos foram unânimes em considerar que as turmas são extremamente heterogêneas durante o ciclo básico, no entanto, o grupo 3 pontuou que o mini osce, um treinamento prático que antecedia a avaliação, colaborava para homogeneização e padronização da turma. Em contrapartida, segundo os grupos 1, 3 e 4, no ciclo clínico, terceiro e quarto ano do curso de medicina, tende a haver uma maior padronização das turmas, pois todos os grupos passam pelos mesmos docentes e supervisores durante o semestre, ou seja, têm a mesma cobrança e são avaliados da mesma forma em cada rodízio dentro das grandes especialidades médicas.

\footnotetext{
${ }^{6}$ As docentes de IESC $\mathrm{V}$,ficaram em $2^{\circ}$. lugar na premiação de práticas pedagógicas inovadoras no 4ํ Prêmio UniCEUB de Mérito Acadêmico em comemoração aos 50 anos de prática pedagógica.
} 
Os alunos dos grupos 1, 2, 3 e 4 consideram que durante o ciclo clínico, momento em que o aluno passa a ter contato com o paciente e a conhecer na prática as manifestações clínicas de determinadas patologias, o mesmo consegue unir a teoria com o que foi visto na prática, o que permite uma maior sedimentação do conhecimento. Para alguns alunos do grupo 1, durante o terceiro ano, no rodízio de clínica médica, foi de grande valor ter recebido orientações construtivas e respeitosas quanto a forma correta de se desenvolver uma anamnese. "A professora dizia assim: "eu faço desse jeito, assim eu acho melhor, mas isso não quer dizer que a forma como você faz está errada." (Grupo 1).

As ações adotadas pelos docentes dentro do eixo de HA, principalmente a partir do ciclo clínico, momento em que o discente passa a atuar nos hospitais sob supervisão direta dos professores, se correlaciona com o estudo realizado por Cezar et al (2010) a medida em que o próprio estudante reconhece suas ações nas atividades práticas e faz associações com a base teórica, orientada pelo professor, processo que favorece a consolidação do conhecimento.

Dentro do eixo de HA, na disciplina de Cirurgia, a proposta preconizada pela metodologia ativa, de ensino em espiral, foi observada por alguns alunos dos grupos 3 e 4, uma vez que os conhecimentos e técnicas cirúrgicas desenvolvidos durante o terceiro ano da graduação são colocados em prática nos anos subsequentes. Prova disso é que, no quarto ano do curso, quando os alunos são inseridos no cenário de prática cirúrgica no hospital, mesmo que tenham a base do terceiro ano, os docentes partem do pressuposto de que o discente não possui habilidades práticas e, a partir de então, explicam minuciosamente todos os procedimentos ao aluno e o acompanham durante todas as atividades, o que contribui para a construção estruturada do conhecimento. Com relação ao primeiro contato que o grupo 3 teve com a matéria eles pontuaram a importância da presença dos monitores durante as aulas práticas, algo distinto do que ocorre há 5 anos, momento em que as monitorias passaram a ser realizadas em horários contrários aos das aulas. Os discentes julgaram a atuação dos monitores como tendo sido um fator determinante na homogeneização das técnicas na turma.

Em relação a disciplina de Profissionalismo, foi unanimidade entre os grupos 1, 3 e 4 a importância em trabalhar o código de ética médica dentro da graduação, tendo em vista que os estudantes aprendem de forma crítica e prática sobre os direitos e deveres do profissional médico. As atividades desenvolvidas em 
Profissionalismo, apesar de consideradas repetitivas pelos grupos 2, 5 e 6, foi considerada importante para todos os grupos uma vez que possibilita o debate de assuntos que não seriam questionados espontaneamente. Dentre essas atividades, as encenações que ocorrem no sexto semestre, para abordar o tema de pacientes psiquiátricos, contribuíram para que os alunos do grupo 2 avaliassem os comportamentos em cada encenação e, a partir daí, definissem as prováveis condutas a serem adotadas. Especificamente para o grupo 1 as atividades de Profissionalismo do quinto semestre foram produtivas, pois foram trabalhados determinados assuntos com especialista na área e, em seguida, havia uma discussão com todo o grupo, o que era enriquecedor pela troca de experiências entre discentes e demais profissionais.

Segundo o projeto pedagógico do UniCEUB (2001), uma das competências do eixo de HA é capacitar o discente para realização de exame físico e procedimentos médicos diversos, bem como ofertar para o aluno técnicas de comunicação social. O último ponto é o foco de Habilidades profissionais que preza pela comunicação efetiva entre médico e paciente, uma vez que a comunicação permite a criação de vínculo e a maior adesão do paciente ao tratamento.

No terceiro semestre, módulo de Saúde da Criança, foi unanimidade entre os grupos focais a integração entre os três eixos principais: HA, IESC e tutorial. Em HA os alunos aprenderam semiotécnica e semiologia pediátrica, no tutorial foi trabalhada a parte teórica e em IESC conseguiram relacionar a parte teórico-prática e aplicá-la na Saúde Pública, uma vez que fizeram consultas de Crescimento e Desenvolvimento nos CS e passaram a acompanhar uma criança nas VD. Especialmente em HA pediátricas no terceiro semestre, a metodologia adotada de envio prévio de pré-teste, depois a discussão dos assuntos e em seguida a prática foi eficaz na percepção de todos os alunos, uma vez que esse modelo direciona o estudo e o grau de aprofundamento dos discentes e, dessa forma, favorece a homogeneidade da turma. "No terceiro semestre, quando tivemos os pré-testes de pediatria, foi quando eu mais aprendi, estudando em casa e discutindo em grupo" (Grupo 6). Essa metodologia de ensino, executada pela coordenadora de HA pediátrica, segue padrões similares aos do eixo tutorial. No entanto, os acadêmicos não formulam por si só os objetivos a serem estudados posteriormente para a discussão, os objetivos são enviados previamente (pré-teste) para os alunos juntamente com as referências bibliográficas que direcionam o estudo. As aulas, 
seguintes ao envio dos pré-testes, ocorrem a partir de discussões embasadas nos objetivos previamente estudados pelos alunos.

\section{2. 2. Limitações e desafios}

Nessa categoria serão apresentadas as considerações dos discentes acerca do que, dentro de cada tópico, consideram que está em desacordo com o previsto na MA e nos dois eixos de ensino.

\section{2. 2. 1- Metodologia ativa e o ABP aplicado no UniCEUB:}

Os alunos de todos os grupos focais compreendem que a metodologia ativa, apesar de apresentar diversos pontos positivos, ainda não é um método bem implantado na instituição UniCEUB. Alunos de todos os grupos consideram que o método quando aplicado a áreas básicas de ensino como anatomia, histologia, patologia, não conseguem suprir as necessidades de conhecimento do aluno, o que acaba se refletindo em dificuldades em outros momentos da graduação: "eu me senti defasado em algumas áreas e eu vi que o método tem uma parcela de culpa nisso" (Grupo 1). A reclamação foi confrontada em todos os grupos focais, pois alguns alunos consideram que esse prejuízo não seja culpa do método em si, mas sim da maneira como ele tem sido implantado do UniCEUB: "acho que o problema está na nossa instituição de ensino e não no método” (Grupo 1).

Alunos do grupo 1 consideram negativa a maneira como a metodologia tradicional é apresentada para os discentes, no UniCEUB, de forma que acreditam que as qualidades de ambas as metodologias devem ser ressaltadas e ao mesmo tempo a instituição tem que "mostrar" as razões que levaram à adoção do método $A B P$. "Não precisa ser do jeito que eles falam, essa demonização [do método tradicional. Eu acho que isso faz falta, a gente pensar também que o método tradicional tem suas qualidades e forma profissionais também". Os alunos do grupo 1 consideram, ainda, que os coordenadores de curso e os docentes posicionam-se de forma intolerante quanto a adoção de um ou outro método, tradicional ou ativo, ao passo que isso traz fortes prejuízos a formação do aluno, pois cada ciclo e cada matéria trabalhada necessitam de métodos diferentes para que 
haja melhor aprendizado. "Pra mim o ideal seria juntar os métodos tradicional e PBL e unir o melhor dos dois mundos" (Grupo 1).

Deve-se salientar, no entanto, que o PBL não deve ser encarado como um método definitivo a ser proposto ao leitor. Pelo contrário, há que se considerar a grande liberdade de formas que pode e deve privilegiar um tipo de aprendizagem que depende da ação conjunta de diferentes atores. Há que se implementar metodologias ativas de aprendizagem, que podem ser um híbrido do PBL com o ensino tradicional ou mesmo uma reconstrução das metodologias problematizadoras, no sentido de fortalecer a capacidade dos estudantes para trabalharem coletivamente, contribuir para uma postura autônoma na resolução de problemas e desenvolver competências para uma efetiva integração das tecnologias na formação docente ( SOUSA e JÚNIOR, 2010, p.244)

Foi unanimidade entre os grupos focais a falta de horário protegido direcionado para o estudo individual como um grande limite, tendo em vista que no ABP esse tempo é fundamental para o processo estudo-aprendizagem, uma vez que nessa metodologia implementada na instituição, o aluno deve ser ativo na busca pelo seu conhecimento. “A gente que vai correr atrás, isso demanda muito mais tempo do que vir e assistir uma aula, porque você tem que ler, refletir o que você está lendo, você tem que internalizar aquilo" (Grupo 1). A falta de tempo questionada pelos alunos, além de interferir no processo de aprendizagem, influencia diretamente na saúde mental dos estudantes, uma vez que os mesmo passam a sacrificar gradualmente suas noites e finais de semana na tentativa de cumprir o que é exigido por todas as disciplinas do curso. "Compromete não só a qualidade de estudo mas a qualidade de vida" (Grupo 5)". A gente não tem saúde mental porque a gente é exigido tanto, exigido tanto, que não temos tempo pra gente" (Grupo 5). Alguns relatam, ainda, a necessidade de sacrificar algumas matérias em detrimento de outras para conseguir estudar e aprofundar no que seria o mais "importante". "Às vezes você quer dedicar um pouco mais do final de semana para outras matérias, ou até pro lazer, que é importante, porque se não a gente só vive pra isso e onde fica o tempo" (grupo 5). Do ponto de vista dos alunos isso acaba por contribuir no desencadeamento de episódios de depressão e outras doenças psiquiátricas no decorrer do curso de medicina.

A questão da saúde mental do estudante de medicina já foi foco de análise em diferentes instituições. Um estudo desenvolvido por Gonçalves (2009) aponta que existe uma tendência, entre os estudantes de medicina, de desencadearem quadros depressivos e de ansiedade. A autora aponta que é importante que haja uma visão diferenciada para os discentes de medicina que são submetidos a situações de estresse e de abuso de poder, por parte do docente, com certa 
frequência e dessa forma tornam-se sujeitos não só a desenvolver quadros depressivos e de ansiedade quanto de cometer suicídio (GONÇALVES; PEREIRA, 2009).

Um dos fatores que, segundo os GF, justifica a restrição de horário protegido para estudo é a adoção do core curriculum na grade horária de medicina. O core curriculum faz parte do currículo escolar de medicina durante todo o ciclo básico e contempla matérias obrigatórias da instituição, UniCEUB, que não necessariamente se relacionam com a área da saúde ${ }^{7}$. Essas matérias sobrecarregam a grade horária do aluno que está em processo de adaptação no curso, além de adotarem a metodologia tradicional. Assim, os alunos consideram que o core curriculum está em desacordo com a metodologia ativa e que alguns temas trabalhados poderiam ser incorporados em um dos eixos educacionais.

O core curriculum é apresentado no projeto pedagógico (2001) como uma atividade inovadora que possibilita que os estudantes tenham contato com áreas diversas nos primeiros anos do curso. São matérias, no entanto, que seguem o padrão tradicional de ensino, o que dificulta o entendimento do aluno, recém ingresso na faculdade, sobre o que de fato é estar inserido em uma metodologia ativa, uma vez que a conduta de docentes e discentes e a explanação do conteúdo são altamente divergentes nas duas formas de metodologia de ensino, conforme exposto por Sousa (2016).

Alguns discentes do grupo 6 revelaram a dificuldade de adaptação ao método no início do curso, julgando ser esse um dos grandes problemas de aproveitamento dos conteúdos durante o primeiro ano de medicina. Devido à dificuldade de adaptação à metodologia proposta, o aluno desenvolve resistências diversas relacionadas ao curso, o que reflete, diretamente, na sua capacidade de aprendizagem. “...Sem eu criar por vontade própria, foi natural, tive muita resistência. Tive muita resistência pra começar. $O$ primeiro semestre foi horrível, eu posso dizer que praticamente não aproveitei nada do meu primeiro ano" (Grupo 6). Sousa e Dourado (2015) avaliam que em alguns casos pode ocorrer dificuldade de adaptação ao método, às vezes relacionada com a maneira como o docente entende e aplica o ABP, fato também trabalhado por Almeida e

\footnotetext{
${ }^{7}$ LIBRAS, Sociologia, Português e Ética.
} 
Batista (2013), e às vezes relaciona-se a uma resistência individual do discente diante do processo adaptativo.

Surgiram diferentes percepções sobre a implementação da MA. Alguns GF afirmam que o método é defasado no Brasil, de forma que, para as noções básicas conteudistas de medicina, como histologia, anatomia, bioquímica, farmacologia, a metodologia ativa não é suficiente, pois é necessário algo além de um livro para se obter o conhecimento nessas áreas. Em contrapartida, outros alunos, de um mesmo grupo focal, afirmam que nos primeiros semestres do curso tiveram algumas aulas expositivas de histologia e de anatomia e que isso seria um ponto negativo por fugir da metodologia proposta, além de apontar tal fato como sendo uma dificuldade enfrentada pela instituição em implantar o método. Uma terceira argumentação acerca da metodologia, diferente das demais e também dentro de um mesmo grupo focal, diz respeito a uma visão de que o método em si não pode ser "xiita" e limitar o conhecimento em ser apenas "ativo" ou apenas "tradicional", pois para cada disciplina, no decorrer da graduação, pode haver melhor aproveitamento em um determinado método de aprendizagem.

As principais categorias que definem o que é ser um bom professor competência técnico-científica, competência pedagógica e formação humanística - revelando que têm consciência da evolução do papel do professor, da complexidade da docência e da necessidade de conhecimentos específicos para exercê-la adequadamente, ou que, no mínimo, é preciso adquirir conhecimentos e habilidades vinculados à atividade docente para melhorar sua qualidade. (...) Um dos itens primordiais para o aprimoramento da docência médica é planejar uma formação pedagógica que integre experiências e vivências docentes com a discussão e o debate de princípios teóricos de educação, oferecendo aos professores uma luz que os ajude a analisar criticamente sua ação e experiências docentes, para que eles consigam encontrar novos e melhores caminhos para seu trabalho (COSTA, CARDOSO e COSTA, 2012, p.503)

Os alunos do grupo 1 acreditam que um ponto levantado como positivo, a responsabilidade individual do discente na construção do saber, pode tornar-se negativo quando o mesmo não recebe as devidas orientações dos docentes: "coloquei como ponto negativo a partir do momento em que eles jogam o peso todo em cima do acadêmico". Às vezes quando surge alguma dúvida, por ser MA, alguns professores não estão dispostos a ajudar e acreditam que a obrigação é inteiramente do aluno. "O professor que não sabe muito coisa, não se sente na obrigação de saber aquele conteúdo porque quem tem que saber é o aluno. Aí você chega com uma pergunta e ele (o professor) fala "não isso aqui é MA você que tem que correr atrás" e não tira sua dúvida" (Grupo 1). Essa realidade 
vivida pelos alunos e expressada de forma angustiante e desapontada é corroborada pela literatura. Almeida e Batista (2013) apontam a importância do docente na construção do saber e colocam que o professor deve assumir papel de facilitador com duas funções importantes: colaborar para adaptação do aluno no novo método de ensino em que está inserido e ser um auxiliar na construção do saber. Tais funções tem fundamental importância, em especial no primeiro período, momento em que o aluno está se familiarizando com a MA.

\section{2. 2. 2- HABILIDADES}

Em relação, especificamente ao ciclo básico, todos os GF expuseram ser nítida a assimetria entre os alunos, fato que reflete a maneira como o docente conduz a matéria e aprofunda o conteúdo em cada pequeno grupo. Os discentes dos grupos 1, 2, 3, 4 e 5 definiram o ciclo básico como sendo superficial, incompleto e repetitivo. Superficial e repetitivo, por explanar com o mesmo grau de profundidade a semiologia cardíaca, pulmonar e abdominal durante os dois primeiros anos do curso; incompleta, por não contemplar de modo adequado a semiologia neurológica, dermatológica e do aparelho locomotor, por exemplo.

Os grupos 1, 3 e 4 revelam que no ciclo clínico essa assimetria se minimiza, pois todos os alunos passam a ter acesso a mesma discussão e são avaliados pelos mesmos docentes. Ainda assim há relatos de alunos do grupo 3 de colegas que chegam ao oitavo semestre do curso sem saber realizar o mínimo necessário para um exame abdominal ou cardíaco correto, por exemplo. Nesse ponto, observa-se uma falha não só do aluno, como da própria instituição de ensino que permitiu que o mesmo completasse dois terços do curso sem ter domínio dos conhecimentos semiológicos básicos.

Nesse contexto podemos observar que o projeto pedagógico (2001) da instituição não tem sido aplicado. No projeto, ao final das sessões de descriminação de cada HA, do primeiro ao quinto semestre, há a descrição do que deveria ter sido ensinado e estudado no formato de check list. Assim, entende-se que o check list, que seria o fator gerador de padronização entre os alunos de cada semestre, não tem sido utilizado pelos professores e nem é acessível aos discentes, os quais em momento algum o citaram. 
Por meio dos grupos focais observamos que ao longo dos cinco anos de implementação do curso de medicina no UniCEUB, o eixo de HA passou por alterações na forma de cobrança do conhecimento do aluno, deixando, nos últimos dois anos, de avaliar os discentes apenas por meio de provas práticas e passando a aplicar, de maneira conjunta, provas prático-teóricas. Os alunos dos grupos 3, 1 e 4 vivenciaram a tentativa de implementação de seminários, depois, juntamente com grupo 2, de discussões em grupo e, mais recentemente, de "mini-tutoriais", segundo os grupos 5 e 6 . Nenhuma das modificações de ensino conseguiu superar a maior crítica destinada ao eixo: a disparidade entre os grupos de alunos de uma mesma turma devido aos diferentes graus de cobranças impostos pelos docentes. Além disso, foi observado no grupo 5 que a nova forma de desenvolvimento da disciplina, exigindo que o aluno trate HA como um "mini-tutorial" prejudica ainda mais a qualidade de estudo do aluno, uma vez que não ocorreram mudanças nos horários protegidos para o estudo individual. Por fim, falta uma padronização no eixo, de modo que os discentes sejam cobrados de forma semelhante e que concluam cada semestre obtendo um "mínimo" delimitado entre os professores e assim sejam nivelados igualmente. "Falta padronização" (Grupo 1).

Um trabalho desenvolvido por Sena et al (2008) discute a importância do docente na construção do conhecimento no modelo de ensino ABP no sentido de ser um guia no desenvolvimento gradual do conhecimento. Essa ideia é confrontada a medida em que os discentes pontuam as assimetrias existentes dentro de uma mesma turma como sendo decorrentes da condução de determinados docentes, dentro de cada subgrupo, ao longo do semestre. Nesse sentido entende-se que a construção do saber tem uma relação estreita com a maneira com que o docente conduz seu pequeno grupo de forma a possibilitar o grau de aprofundamento adequado, a cada conteúdo, em determinado momento do curso. Kahwage Neto (2017) defende ainda da importância de se trabalhar o exame físico (EF) dentro da graduação médica, de forma a padronizar, dentro da graduação, as etapas do exame e da anamnese por meio de roteiros, de forma que a execução do EF associada a $\mathrm{HC}$ culmine em achados norteadores de um diagnóstico mais assertivo.

No eixo de HA, na parte de Habilidades Profissionais, mais conhecida como profissionalismo, a falta de cronograma foi um fator criticado por todos os grupos avaliados, os quais dizem já terem solicitado mudanças junto à coordenação e aos docentes, mas sem êxito. "Até hoje não tem cronograma” (Grupo 3). Apesar dos 
grupos 1 e 3 afirmar que os conteúdos trabalhados são importantes, explicitam que os conteúdos são vagos, repetitivos e pouco aproveitados da maneira como é aplicado. Mais de um grupo afirmou, grupos 3, 5 e 6, que os professores questionam na primeira aula do semestre: "O que vocês querem fazer hoje?". E diante do exposto e dos debates pouco reflexivos os alunos questionam a necessidade de ter uma matéria separada para essas discussões, acreditando que, da forma como têm sido ministradas as aulas, as discussões podem ser diluídas em outros eixos "Como eles querem formar médicos mais humanos? Que tipo de discussão eles querem trazer pra gente?" (Grupo 5). 0 grupo 3 relata ter passado pela disciplina em um semestre sob a coordenação de um psiquiatra que conseguiu abordar 0 conteúdo proposto de maneira inteligente, clara e proveitosa, seguindo sempre um cronograma, o que sugere que a conduta do docente influencia diretamente no grau de aprendizagem e interesse dos graduandos. A abordagem do código de ética médica, no sexto semestre do curso durante as aulas de Profissionalismo, tem como limitação o pequeno número de aulas para o grupo 1 e 4, o que implica em pouco aprofundamento em um tema considerado tão importante para a formação médica.

O projeto pedagógico não prevê o que deve ser trabalhado a cada semestre na disciplina Profissionalismo, que compõe o eixo de HA, apenas pontua alguns temas considerados de maior relevância e que devem ser discutidos ao longo das aulas. O projeto tem como foco principal, para a disciplina, que o discente desenvolva habilidade de construir, de maneira efetiva, a relação médico-paciente. Dessa forma, o documento permite que a matéria utilize diferentes meios de ensino para que o objetivo seja alcançado pela maior parte dos discentes.

No terceiro ano do curso de medicina o eixo de HA inclui habilidades cirúrgicas, onde é esperado que os alunos adquiram conhecimentos tanto teóricos quanto práticos e desenvolvam habilidades técnico-manuais para realizar procedimentos invasivos (UniCEUB, 2001). No entanto, há também na disciplina de HA cirúrgicas uma nítida assimetria entre os alunos, a qual está relacionada a essa falta de sincronia entre os professores e a falta de um roteiro unificado para ser seguido durante o semestre, de modo que foi relatado em todos os GF que um subgrupo abordou um determinado conteúdo que não foi ensinado aos demais, criando assim uma discrepância entre os alunos de uma mesma turma. Segundo os GF, a avaliação prática no final do semestre, que deveria ser utilizada para avaliar se todos os alunos daquele semestre estão aptos à próxima etapa do curso, é 
despadronizada entre os grupos de uma mesma turma, seguindo uma cobrança individual de cada professor, ou seja, não é estabelecido o mínimo de conhecimento que cada discente deve adquirir para estar apto a avançar para o próximo semestre. Há, no entanto, a descrição no projeto pedagógico de todos os procedimentos que os alunos devem aprender e treinar em HA cirúrgicas, os quais nitidamente não são abordados por todos os docentes.

Outro fator relevante para que se tenha êxito na disciplina de habilidades cirúrgicas e que foi questionado pelos grupos 3, 5, 6 e final é o material disponibilizado para que os alunos sejam treinados e desenvolvam aptidão em relação às técnicas de procedimentos invasivos e mais complexos. Os discentes relataram que há uma certa deficiência em alguns materiais oferecidos pela instituição, tendo em vista que alguns simuladores de procedimentos invasivos são limitados para que os estudantes aprendam a técnica adequada, ou por serem de má qualidade, ou por estarem velhos, ou por serem ofertados em pequena quantidade. Além disso, foi relatado também que alguns docentes são despreparados quanto ao uso desses simuladores e, não sabendo manuseá-los, não conseguem treinar os alunos de maneira eficaz.

\section{2. 2. 3- IESC}

Em relação ao eixo de IESC, todos os grupos, exceto o grupo 6, concordaram que há uma contradição dentro da metodologia, pois, o aluno que deveria ser ativo, é colocado em lugar de sujeito passivo, sendo limitado a apenas observar o que acontece no Centro de Saúde sem que haja uma discussão mínima acerca das condutas adotadas pelos profissionais de saúde. Para todos os grupos falta que 0 aluno esteja melhor inserido nas atividades práticas do Centro de Saúde, atuando de forma mais ativa em atendimentos e em ações de promoção de saúde e prevenção de agravos.

As constantes mudanças na metodologia do eixo de IESC é o que desmotiva a maioria dos alunos, de todos os grupos, tendo em vista que algumas turmas já passaram por três métodos de ensino diferentes durante a graduação, tais como aula expositiva, seminários e atualmente TBL. Todos os GF concluíram que, muitas vezes, o corpo docente não está preparado para tais mudanças de metodologia e ao não compreendem os novos métodos não conseguem aplicá-los de forma 
satisfatória e nem orientar os discentes. Outro problema levantado pelos grupos 2, 4, 3 e 6, com relação ao método adotado, o TBL, diz respeito à carga de conteúdos cobrados, a qual não é compatível com o tempo disponível para estudo, tendo em vista que as Políticas de Saúde, estudadas no eixo, são extensas e não há uma delimitação, por parte dos docentes, dos pontos-chave que os estudantes devem conhecer e aprofundar. Dessa forma, somando a grande carga de conteúdo, a falta de direcionamento e a falta de horário protegido para IESC, o resultado não é satisfatório. Além disso os discentes de todos os grupos questionam o nível de cobrança que tem sido exigido. Para os grupos 1, 2, 3 e 4 os testes exigem apenas uma capacidade de memorização de dados e não de reflexão acerca do que foi previamente estudado. "A professora coloca lá que são $20 \%$ das mulheres, mas na verdade são $19 \%$ e por causa disso a questão tá errada" (Grupo 2). "É uma vergonha as questões dos testes. Beira o ridículo" (Grupo 4). Os alunos do grupo 4 expuseram que a não disponibilização do cronograma inviabiliza que o aluno estude todo o conteúdo de acordo com a disponibilidade que possui e sem que haja sobrecarga.

A aprendizagem baseada em equipes ( $\mathrm{BBE}$ ) do inglês team-based learning (TBL) foi a metodologia ativa adotada no eixo de IESC desde o segundo semestre de 2017. No artigo de Bollela et al (2014) são apresentadas as 3 etapas de execução do método, sendo elas: preparação individual; avaliação da garantia de preparo e a aplicação dos conhecimentos adquiridos. Nesse sentido, as limitações apontadas pelos discentes abrangem principalmente as duas primeiras etapas. $\mathrm{Na}$ etapa 1 é questionado o material de estudo pré-classe, o qual, sendo uma política de saúde ou uma diretriz, por exemplo, é extremamente extenso e merece um direcionamento prévio para os discentes entenderem o foco que deve ser dado, o que não acontece na prática. A etapa 2 que, segundo Bollela et al (2014), abrange os conceitos fundamentais das atividades previstas e da bibliografia previamente indicada", é apresentada como uma limitação pelos alunos, pois os mesmos são cobrados de um maneira que, muitas vezes, avalia apenas a capacidade de memorização de dados.

As constantes mudanças na metodologia do eixo de IESC indicam, por um lado, o esforço da coordenação em desenvolver uma disciplina que tenha resultados cada vez mais efetivos para os discentes. Além disso, na tentativa de melhorar esse eixo de ensino, há um espaço dentro do cronograma de IESC (última aula do 
semestre) para que as limitações observadas pelos alunos sejam expostas aos professores, de forma que ocorre uma avaliação da disciplina, das atividades e dos docentes a cada semestre. No entanto, os alunos de todos os grupos afirmaram que os professores, e a própria coordenação, não levam em consideração as propostas e as reclamações e com isso o erro tem se perpetuado ao longo dos semestres. "E no final de cada semestre, do primeiro e do segundo, a gente fez uma avaliação oral do semestre. Todo mundo reclamou de tudo que estava errado, os professores falaram um monte de coisas. No segundo semestre estava a mesma coisa" (Grupo 2). Dessa forma, Sena et al (2008) salientam a importância do feedback do discente para instituição e para o docente no cenário de ensinos com enfoque na metodologia ativa, pois é nesse momento que a MA pode se reconfigurar e promover melhorias nas instituições e no próprio corpo docente.

Os grupos 2 e 3 salientaram que em determinados IESC as atividades realizadas nos diversos cenários de saúde foram destoantes entre os subgrupos, à medida que em alguns subgrupos os alunos conseguiam realizar exames de rotina e em outros era realizada uma festa junina no centro de saúde. Para os discentes essas situações desfavorecem a disponibilização de conhecimentos de forma uniforme entre os alunos: "Como é que você vai construir um conhecimento com uma turma, se cada grupo faz uma coisa completamente diferente?" (Grupo 2)". É nesse sentido que os discentes discriminam cada IESC como bom ou ruim. Isso explica o posicionamento do grupo 2 diante de IESC 3, o IESC considerado perfeito por quase todas as turmas. Para o grupo 2 IESC em pediatria não funcionou, pois não era permitido aplicar o que se aprendia em HA na disciplina de IESC, diferente do que ocorreu nas demais turmas a teoria não estava sendo aplicada na prática.

Os grupos 3 e 4 levantam uma questão intrigante com relação a IESC no quarto ano, momento em que o aluno começa a ser mais atuante nas atividades intra-hospitalares no eixo de HA. Os discentes questionam as vantagens de participar de IESC apenas como observador de atendimentos médicos, uma vez que já atuam de forma mais efetiva e aprofundada em HA: "o sétimo semestre a gente tá atendendo já no hospital, enfiava a gente no consultório pra ficar vendo consulta (em IESC)" (Grupo 4).

Para os grupos 2 e 3 outra grande falha observada pelos discentes no eixo é que os estudantes são limitados a conhecer as funções desempenhadas pelo 
Agente Comunitário de Saúde (ACS), sem saber as reais funções de enfermeiros e técnicos de enfermagem preconizadas pelo SUS. Dentro disso os alunos salientaram que não sabem exatamente qual o papel do médico da família e como eles de fato atuam no posto de Saúde e nas VD. "A gente não vê o papel do médico, a gente vê o ACS" (Grupo 2). Além disso, para os grupos 2 e 3 falta uma comunicação direta entre os estudantes e o Médico da Família e Comunidade (MFC), o que prejudica tanto a compreensão dos alunos sobre a funcionamento do programa de Estratégia de Saúde da Família (ESF), quanto à abordagem dos pacientes na comunidade pelo próprio MFC. Segundo um aluno do grupo 3, atualmente no internato, a compreensão de como funciona a ESF, de fato, só ocorreu quando o mesmo foi inserido na Atenção Básica e teve contato direto com o MSF. "(IESC) eu acho muito perdido, é como se fosse muito à parte. A gente não consegue integrar o que a gente vê no IESC" (Grupo 2).

As falhas apontadas vão contra os objetivos específicos do projeto pedagógico para o curso de medicina (2001, p. 235):

2. Conhecer e refletir sobre os principais problemas de saúde de uma determinada comunidade;

3. Integrar-se às Equipes de Saúde da Família, propor e desenvolver alternativas de solução para problemas de saúde dessa comunidade.

Ainda dentro do projeto pedagógico, nas páginas seguintes à citada anteriormente, são definidos os papéis do aluno, do professor e do colaborador. Nesse sentido vemos que há uma discordância em um dos pontos sobre o papel do aluno, uma vez que, no avançar dos semestres, o aluno não participa de atividades mais complexas.

No início do curso, nas primeiras etapas, as atividades dos alunos serão desenvolvidas juntamente com os Agentes Comunitários de Saúde, com contacto mais próximo com a comunidade do território de cobertura de cada Equipe de Saúde da Família. Com o avançar nos semestres do Curso o aluno começa a participar em atividades mais complexas na Unidade de Saúde da Família, incluindo as práticas médicas. (UniCEUB, 2001, p.236 )

As atividades práticas em IESC às vezes são percebidas como pouco produtivas no cenário: ou por falta de organização, ou por serem aulas expositivas que poderiam ocorrer no UniCEUB. Dessa maneira, os alunos de todos os grupos se queixam de se deslocarem para um lugar distante e não terem proveito quanto ao conteúdo oferecido na atividade.

$\mathrm{Na}$ perspectiva das visitas domiciliares, os discentes dos grupos 1, 3 e 4 se sentem limitados pelo fato de não terem contato com a equipe de saúde da Família, principalmente um MFC, o que dificulta a conduta, como por exemplo, na solicitação 
de exame e no agendamento de consultas. Os estudantes dos grupos 3 e 4 não se sentem resolutivos nas VD, afirmando que em algumas famílias não conseguem fazer uma intervenção que seja eficaz, de modo que o próprio sistema de saúde não permite que todos os problemas sejam resolvidos eficientemente, como falta de médico na UBS, por exemplo, o que, por um lado, coloca o estudante em contato com os desafios do mundo real.

O problema de IESC, no caso da VD, é o que acontece no Brasil. O
projeto de Sáude da Família ainda está sendo implementado, ainda não
funciona da forma que gostaríamos que funcionasse. Uma mulher da
família que eu acompanho precisa de uma consulta ginecológica mas
no Posto de Saúde não tem Ginecologista. Logo, é um problema
relacionado ao próprio país e que vai, muitas vezes, além da
capacidade do UniCEUB em resolver" (Grupo 4).

Além disso, os grupos 3 e 4 afirmam que não há uma continuidade das ações desenvolvidas para as famílias acompanhadas durante a graduação, sendo que o grupo 3 refere que isto acontece por falta de um documento, que seja de fácil acesso para discentes, ACS e docentes, e que relate tudo o que já foi proposto durante os semestres e tudo o que já foi alcançado para cada família e que, por isso, há certa dificuldade em garantir a continuidade do cuidado, tendo em vista que a cada semestre há um novo supervisor e um novo docente. Apesar de haver documentado, nos relatórios das atividades práticas de IESC, tudo o que foi vivenciado e executado pelos alunos nas VD, os docentes do semestre subsequente, geralmente, não têm acesso a esses documentos para dar continuidade às ações. Os relatórios das atividades práticas de IESC são proveitosos de acordo com o docente que acompanha cada grupo e, por isso, cria-se, mais uma vez, um espaço para que haja assimetria entre os alunos, por serem exigidos de maneira diferente. Dessa forma, para os grupos 1 e 2 a atividade se torna mais eficaz quando os professores têm o compromisso e o hábito de ler e corrigir os relatórios, dentro de um prazo determinado, fazendo um feedback para o aluno acerca da revisão bibliográfica e suas conclusões. E, a partir de então, o discente é capaz de melhorar sua argumentação, seu entendimento e inclusive melhorar seu desempenho nas próximas atividades. Entretanto, quando o docente não cumpre com a proposta metodológica da disciplina, a mesma não é efetiva. Com relação a entrega de portfolios, que ocorre todo final de semestre no eixo de IESC, o grupo 2 e 4 apontou a falta de continuidade entre as atividades, uma vez que os relatórios e os projetos terapêuticos contidos no material nem sempre são avaliados e devolvidos pelos docentes o que dificulta a evolução do aluno. 
Há também uma assimetria entre os grupos em IESC, a depender dos supervisores que os acompanham, ideia exposta principalmente pelo grupos 2, $3 \mathrm{e}$ 5 , sendo que alguns desses supervisores conseguem auxiliar nas ações, com agendamento de consultas e exames, por exemplo, e outros não oferecem o suporte básico necessário para que os alunos consigam ser minimamente resolutivos. Com relação a VD o grupo 2, 3 e 6 reclamam da desorganização na marcação de VD e salientam a importância em confirmar as visitas com as famílias, bem como de saber se as famílias querem ser acompanhadas. As ideias vão de encontro ao que é apresentado por Santos et al (2015, p.134) com relação às limitações existentes nas atividades:

\begin{abstract}
Apesar da integração à comunidade ter sido proveitosa, alguns aspectos revelaram necessidades de mudanças para que se possa extrair melhores resultados dessa estratégia, fato notado nas perguntas referentes às oportunidades para desenvolvimento de habilidades práticas, nas quais houve uma divisão de opiniões. Enquanto a maioria relatou ser possível a realização de exame físico e de opinar sobre diagnóstico ou tratamento, outra parcela significativa afirmou não poder realizar anamnese e dar opiniões sobre exames complementares. Segundo os acadêmicos, esse ponto poderia ser melhorado se os preceptores conhecessem melhor sua função, o que padronizaria as atividades.
\end{abstract}

A problematização é uma atividade desenvolvida dentro de todos os IESC's em que os alunos levantam um determinado problema observado na realidade da comunidade, pesquisam sobre o tema e, tendo um embasamento teórico, discutem em sala de aula e criam metas para a resolução do problema inicialmente observado. No entanto, em alguns grupos, dentro de uma mesma turma, falta orientação por parte dos professores em como desenvolver a problematização na prática e, muitas vezes, as etapas da problematização não são cumpridas, ficando apenas no campo da teoria (Grupos 3 e 4). Alguns alunos consideram que a maneira como a problematização começou a ser feita desde a adoção do TBL tem melhores reflexos no poder crítico dos alunos acerca dos problemas levantados (grupo 1 e 6).

Segundo Ritt (2014), o PTS é um conjunto de propostas terapêuticas que considera o paciente de forma holística e que é produzido a partir de discussões com a equipe multidisciplinar, considerando as individualidades e possibilidades do indivíduo ou do coletivo que se está analisando. O PTS é produzido após debate levantado a partir da identificação dos problemas. Nesse sentido, o TBL possibilita que haja um debate diversificado sobre as intervenções que pretende-se adotar para um indivíduo/família, ainda que não seja a discussão ideal, no formato 
multidisciplinar. A partir das discussões e da escuta de pontos de vistas diferentes o discente passa a olhar o caso por diferentes ângulos e a considerar novas condutas ou adoção de novas posturas a fim de conseguir realizar promoção de saúde e prevenção de agravos e dessa forma nasce o PTS produzido pelos alunos e entregue as famílias.

\section{2. 3. Propostas}

As propostas sugeridas pelos discentes nos sete grupos focais realizados serão explicitadas a seguir, na forma de tabela, na mesma ordem adotada nas sessões anteriores: metodologia ativa no UniCEUB; IESC; HA (clínica, profissionalismo e cirúrgica). A tabela é composta por 2 colunas principais: problema apresentado e solução proposta pelos próprios discentes.

\subsubsection{METODOLOGIA ATIVA aplicada na instituição de ensino UniCEUB e a} atuação dos docentes:

\begin{tabular}{|l|l|}
\hline \multicolumn{1}{|c|}{ Problema apresentado } & \multicolumn{1}{|c|}{ Solução dos discentes } \\
\hline $\begin{array}{l}\text { A metodologia ativa não consegue fornecer } \\
\text { ao discentes, de maneira eficiente, } \\
\text { conhecimentos das disciplinas que } \\
\text { compõem a base do curso de medicina, } \\
\text { como anatomia, histologia e farmacologia. }\end{array}$ & $\begin{array}{l}\text { Adotar uma metodologia mista associando } \\
\text { o que há de melhor no método tradicional e } \\
\text { na metodologia ativa para que o processo } \\
\text { ensino-aprendizagem seja mais eficaz. }\end{array}$ \\
\hline $\begin{array}{l}\text { Alguns docentes lidam com o método de } \\
\text { maneira equivocada e se tornam agentes } \\
\text { passivos, depositando a responsabilidade } \\
\text { de aprendizagem no aluno e fugindo ao } \\
\text { papel de orientador e facilitador. }\end{array}$ & $\begin{array}{l}\text { O professor deve atuar como orientador e } \\
\text { dessa forma ser capaz de tirar dúvidas, } \\
\text { indicar literatura pertinente e assumir o } \\
\text { papel de facilitador, aproximando o aluno } \\
\text { do conhecimento. }\end{array}$ \\
\hline $\begin{array}{l}\text { Os alunos afirmam que suas reclamações } \\
\text { não são devidamente respondidas por } \\
\text { alguns docentes e pela instituição. Esse fato } \\
\text { gera insatisfação nos discentes com relação } \\
\text { ao método implantado na instituição. }\end{array}$ & $\begin{array}{l}\text { Validar as reclamações levantadas pelos } \\
\text { alunos, } \\
\text { coordenação. }\end{array}$ \\
\hline $\begin{array}{l}\text { tanto docentes, } \\
\text { Horários reservados para } \\
\text { extremamente reduzidos na grade horária } \\
\text { do curso de medicina, o que dificulta a a } \\
\text { adaptação ao método de ensino e e } \\
\text { compromete o estudo mais aprofundado } \\
\text { dos conteúdos. }\end{array}$ & $\begin{array}{l}\text { Retirar o core curriculum da grade } \\
\text { curricular do curso de medicina, tendo em } \\
\text { vista não haver carga horária de estudo } \\
\text { dirigido condizente com o que se exige do } \\
\text { aluno de metodologia ativa. }\end{array}$ \\
$\begin{array}{l}\text { O curso cuja base de ensino é MA tem que } \\
\text { funcionar, dentro da instituição analisada, } \\
\text { no mesmo período letivo que os demais }\end{array}$ & $\begin{array}{l}\text { Desvincular o calendário acadêmico do } \\
\text { curso de Medicina dos demais cursos na } \\
\text { Instituição, tendo em vista que a }\end{array}$ \\
\hline
\end{tabular}




\begin{tabular}{|c|c|}
\hline cursos que funcionam no modelo de MT. & $\begin{array}{l}\text { metodologia proposta é diferente e não se } \\
\text { adequa ao calendário de um método } \\
\text { tradicional. Dessa forma, diluir os } \\
\text { conteúdos, permite que os alunos tenham } \\
\text { mais tempo para estudar, aprofundar e } \\
\text { assimilar cada assunto. }\end{array}$ \\
\hline $\begin{array}{l}\text { Os alunos dentro da MA são avaliados } \\
\text { através da sua capacidade de participação, } \\
\text { tendo então papel central na sua formação. } \\
\text { Porém, deve-se considerar que há alunos } \\
\text { que não conseguem, ou não se sentem à } \\
\text { vontade para falar em público, e que são } \\
\text { "obrigados" à falar pois estão sendo } \\
\text { constantemente avaliados pelos } \\
\text { professores }\end{array}$ & $\begin{array}{l}\text { Estimular a comunicação dos alunos, } \\
\text { principalmente os mais tímidos, através de } \\
\text { profissionais destinados ao atendimento } \\
\text { desses estudantes, de forma que consigam } \\
\text { se comunicar melhor, tendo em vista que o } \\
\text { método exige isso do aluno. }\end{array}$ \\
\hline
\end{tabular}

\section{2. 3. 2. IESC}

\begin{tabular}{|c|c|}
\hline Problema apresentado & Solução dos discentes \\
\hline $\begin{array}{l}\text { Por se tratar de uma MA os discentes } \\
\text { precisam de direcionamentos de estudos } \\
\text { bem delimitados, tendo sempre objetivos a } \\
\text { serem alcançados. }\end{array}$ & $\begin{array}{l}\text { Organizar o eixo de IESC como o eixo de } \\
\text { tutorial, com objetivos bem delimitados e } \\
\text { posteriormente discutidos. }\end{array}$ \\
\hline $\begin{array}{l}\text { IESC tem como foco os temas básicos que } \\
\text { envolvem as grandes áreas da medicina, } \\
\text { como saúde da mulher e da criança, mas } \\
\text { para os discentes outros temas deveriam } \\
\text { ser abordados a fim de preparar o } \\
\text { graduando para a realidade de diferentes } \\
\text { grupos sociais. }\end{array}$ & $\begin{array}{l}\text { Abordar em IESC outros tipos de grupos } \\
\text { sociais, como a saúde do indígena, por } \\
\text { exemplo, com atividades práticas na Casa } \\
\text { de Apoio à Saúde do Índio (CASAI). }\end{array}$ \\
\hline $\begin{array}{l}\text { O conteúdo do primeiro ano do eixo de } \\
\text { IESC acaba se repetindo, porém não ocorre } \\
\text { um grau de aprofundamento maior de um } \\
\text { semestre para outro. }\end{array}$ & $\begin{array}{l}\text { Integrar os conteúdos de IESC } 1 \text { e } 2 \text { em um } \\
\text { único semestre. }\end{array}$ \\
\hline $\begin{array}{l}\text { Falta de preparo prévio dos alunos para as } \\
\text { atividades práticas, tanto nas VD como nas } \\
\text { UBS. }\end{array}$ & $\begin{array}{l}\text { Preparar os estudantes, a partir de } \\
\text { discussões teóricas em sala de aula, para } \\
\text { que conheçam sobre o funcionamento das } \\
\text { UBS e as condutas nas VD antes de irem ao } \\
\text { cenário e saibam como atuar, o que devem } \\
\text { e não devem fazer, durante as atividades. }\end{array}$ \\
\hline $\begin{array}{l}\text { A quantidade de VD que existem no } \\
\text { decorrer do semestre não torna possível } \\
\text { que o discente, em um mesmo semestre, } \\
\text { perceba se a família acompanhada } \\
\text { conseguiu ou não aplicar as sugestões do } \\
\text { PTS. }\end{array}$ & $\begin{array}{l}\text { Sistematizar as VD de modo que houvesse, } \\
\text { no mínimo, três etapas: coleta de dados } \\
\text { para construção do PTS; entrega do PTS } \\
\text { para a família e aplicação do PTS; avaliação } \\
\text { da adaptação da família quanto às } \\
\text { propostas no PTS. }\end{array}$ \\
\hline $\begin{array}{l}\text { Apesar de todos os discentes terem que } \\
\text { produzir, durante os } 4 \text { anos de curso, o PTS, } \\
\text { todos relataram não ter uma aula destinada } \\
\text { a esse tipo de atividade, o que dificulta a } \\
\text { produção de projetos eficientes. }\end{array}$ & $\begin{array}{l}\text { Introduzir na grade de IESC uma aula } \\
\text { destinada, exclusivamente, à construção e } \\
\text { aplicação de um PTS ANTES do início das } \\
\text { VD. }\end{array}$ \\
\hline Apesar de, no eixo de IESC, o foco ser a & \\
\hline
\end{tabular}




\begin{tabular}{|l|l|}
\hline $\begin{array}{l}\text { atuação do médico na sociedade os alunos } \\
\text { têm pouco, ou nenhum contato, com os } \\
\text { médicos da família e comunidade. }\end{array}$ & $\begin{array}{l}\text { aos alunos como a consulta nas UBS e nas } \\
\text { VD devem ser conduzidas, demonstrando } \\
\text { as etapas necessárias até que o paciente } \\
\text { chegue ao médico. }\end{array}$ \\
\hline $\begin{array}{l}\text { Presença de docentes que não são } \\
\text { preparados, de modo eficaz, para } \\
\text { conduzirem a disciplina de IESC. }\end{array}$ & $\begin{array}{l}\text { Investir em docentes que tenham } \\
\text { experiência nos assuntos abordados em } \\
\text { cada semestre de IESC para que saibam } \\
\text { orientar corretamente os alunos e prepará- } \\
\text { los para o futuro profissional da rede de } \\
\text { saúde. }\end{array}$ \\
\hline $\begin{array}{l}\text { Superficialidade na abordagem de temas } \\
\text { relevantes para a atuação do profissional } \\
\text { médico, como Políticas Públicas de Saúde e } \\
\text { as cadernetas do Ministério da Saúde. }\end{array}$ & $\begin{array}{l}\text { Aprofundar as discussões acerca das } \\
\text { Políticas Públicas, de modo que haja maior } \\
\text { direcionamento dos alunos quanto ao que é } \\
\text { mais relevante para a atuação profissional, } \\
\text { e Cadernetas da criança, do adolescente, da } \\
\text { mulher e do idoso durante o semestre. }\end{array}$ \\
$\begin{array}{l}\text { Debater sobre o trabalho em equipes } \\
\text { multidisciplinares e a importância dessa } \\
\text { tarefa para comunidade e para melhor } \\
\text { elaboração de PTS e melhor execução de } \\
\text { condutas terapêuticas. }\end{array}$ & $\begin{array}{l}|c| \\
\text { Ampliar o contato dos graduandos de } \\
\text { medicina com os estudantes de outras } \\
\text { áreas da saúde, por meio de atividades conjuntas nos cenários propostos } \\
\text { pela instituição. }\end{array}$ \\
\hline
\end{tabular}

\section{2. 3. 3. HABILIDADES clínicas, cirúrgicas e profissionais na graduação médica}

\begin{tabular}{|c|c|}
\hline Problema apresentado & Solução dos discentes \\
\hline $\begin{array}{c}\text { Assimetria entre os alunos de uma mesma } \\
\text { turma por um modelo de cobrança } \\
\text { diferente nos subgrupos de HA, de acordo } \\
\text { com cada docente. }\end{array}$ & $\begin{array}{c}\text { Aplicar em todo o eixo de HA o método de } \\
\text { pré-teste proposto, e visivelmente efetivo, } \\
\text { no terceiro semestre. }\end{array}$ \\
\hline $\begin{array}{c}\text { A falta de cronograma dificulta, para o } \\
\text { discente, compreender o que deve ser } \\
\text { estudado e o quanto aprofundar o } \\
\text { conhecimento em cada semestre. }\end{array}$ & $\begin{array}{c}\text { Estabelecer e fazer ser seguido, } \\
\text { principalmente pelos docentes, um } \\
\text { cronograma de HA que pontue o mínimo } \\
\text { necessário a ser aprendido em cada } \\
\text { semestre por todos os estudantes de } \\
\text { forma a homogeneizar a turma. }\end{array}$ \\
\hline $\begin{array}{c}\text { Os procedimentos invasivos ensinados no } \\
\text { ciclo clínico só serão realizados, pela } \\
\text { maioria dos alunos, no internato e dessa } \\
\text { forma é importante ter treinamento em } \\
\text { manequins que se assemelhem ao corpo } \\
\text { humano. }\end{array}$ & $\begin{array}{c}\text { Melhorar a qualidade dos materiais } \\
\text { oferecidos pela instituição, como os } \\
\text { manequins, para aprimoramento das } \\
\text { técnicas cirúrgicas e de procedimentos } \\
\text { invasivos. }\end{array}$ \\
\hline
\end{tabular}




\begin{tabular}{|c|c|}
\hline $\begin{array}{c}\text { A integração entre os ensinamentos dos } \\
\text { diferentes eixos possibilita maior } \\
\text { assimilação do conteúdo e aplicação, na } \\
\text { prática, dos conhecimentos. }\end{array}$ & $\begin{array}{c}\text { Deslocar Profissionalismo do quinto para } \\
\text { o sexto semestre para que haja integração } \\
\text { com a matéria de Psiquiatria estudada no } \\
\text { eixo tutorial. }\end{array}$ \\
\hline $\begin{array}{c}\text { Falta de eficácia nas atividades da } \\
\text { disciplina de Profissionalismo que } \\
\text { propõem um simulação de casos clínicos } \\
\text { entre os próprios alunos. }\end{array}$ & $\begin{array}{c}\text { Profissionalismo com artistas contratados } \\
\text { e preparados pelos docentes para que as } \\
\text { atividades sejam mais eficazes, como já é } \\
\text { feito nas avaliações de HA clínicas no ciclo } \\
\text { clínico. }\end{array}$ \\
\hline $\begin{array}{c}\text { É muito importante para o novo } \\
\text { profissional da saúde saber e entender o } \\
\text { que deve ou não fazer e como suas ações } \\
\text { podem refletir na sua carreira médica. }\end{array}$ & $\begin{array}{c}\text { Aprofundar, em Profissionalismo, no } \\
\text { conteúdo sobre o código de ética médica e } \\
\text { aumentar o número de aulas destinadas } \\
\text { para tal assunto. }\end{array}$ \\
\hline
\end{tabular}

4. 2. 3. 4. SINERGISMO entre os eixos de IESC e HA

\begin{tabular}{|l|l|}
\hline \multicolumn{1}{|c|}{ Problema apresentado } & \multicolumn{1}{c|}{ Solução dos discentes } \\
\hline Em algumas turmas os discentes não são & Integrar o eixo de IESC e HA para que os \\
autorizados a aplicar os conhecimentos de & alunos sejam estimulados a aplicar os \\
HA em IESC. & $\begin{array}{l}\text { conhecimentos de um eixo no outro para } \\
\text { que assim haja um crescimento paralelo e } \\
\text { uma complementação do conhecimento } \\
\text { dentro do processo ensino-aprendizagem }\end{array}$ \\
\hline
\end{tabular}

\section{2. 4. Percepção dos discentes acerca da relevância do trabalho}

A pergunta finalizadora dos GF foi "Como você considera que os resultados deste estudo possam contribuir para a instituição de ensino, discentes e docentes?". Praticamente todos os discentes mostraram-se esperançosos e declararam acreditar que, talvez, por meio desta pesquisa, a instituição reconsidere algumas condutas adotadas, não apenas com relação ao funcionamento dos eixos, mas também com relação as reclamações direcionadas aos mesmos problemas desde a abertura do curso. "É reclamação baseada em evidencias!" (Grupo 3). Os alunos veem o presente estudo como um veículo de validação das suas angústias diante do que vivem. "Cada vez mais a gente percebe que a coordenação não está nem aí. Se eles prestarem atenção e perceberem que o pensamento das turmas converge, eu acho que teríamos um argumento forte o suficiente para melhorar bastante coisa aqui" (Grupo 6). 
Alguns discentes do grupo 3, devido experiências anteriores em apresentar críticas e propostas de mudanças à coordenação, demonstraram descrença em mudanças na instituição, ainda que os dados levantados representem a formalização de uma realidade vivenciada há 4 anos por diferentes turmas. Ainda assim, foi unanimidade entre os grupos a importância do trabalho que poderá colaborar para melhorias da faculdade de medicina mais nova do Distrito Federal, uma vez que são apresentadas potencialidades, limitações e propostas de mudanças. "A mentalidade diverge muito a depender do esclarecimento e o trabalho de vocês vai trazer exatamente isso, esclarecimento para todos!" (Grupo 3). "Acho que esse trabalho vai ajudar (...) a gente com coisas que a gente sempre reclamou para melhorar o curso!" (Grupo 4).

Os alunos dos grupos 1, 4 e do grupo final pontuaram que a falta de esclarecimentos com relação aos questionamentos levantados pelos discentes, seja por falta de professores, falta de padronização das aulas, atrasos nas aulas, falta de cronograma, geram uma angústia muito grande entre os graduandos de maneira que se a coordenação de dispusesse a dar esclarecimentos, antes que as reclamações surgissem em grande volume, a instituição funcionaria de forma mais eficiente. "Tudo é uma questão de comunicação! (Grupo final)".

Foi unanimidade entre os grupos a necessidade de organização entre os docentes de um mesmo eixo e da própria instituição. Os discentes expõem que vários problemas seriam resolvidos com a disponibilização de cronogramas e de check list no início das aulas, o que direcionaria os discentes e favoreceria uma uniformização dos alunos. "É uma atitude muito simples divulgar o plano de ensino e pedir pros alunos cobrarem dos professores" (Grupo 4). "A gente dá o problema, a gente já dá com a solução. Eles têm o dinheiro (...) às vezes nem é o dinheiro, é falta de remanejar algumas coisas. Falta de organização!" (Grupo final).

Por fim todos os grupos afirmaram, e as pesquisadoras acreditam, que 0 UniCEUB tem potencial para ser uma das melhores faculdades de medicina do DF, uma faculdade de destaque, pois além de possuírem um corpo docente capacitado e empenhado possui discentes dispostos a se adequar as exigências feitas. Assim, se os dados levantados forem considerados relevantes pela instituição haverá homogeneidade entre os graduandos, organização e comunicação fatores cruciais para os futuros profissionais médicos que representam o UniCEUB em todo o país. 


\section{INTERPRETAÇÃO E REINTERPRETAÇÃO}

Nessa seção será realizada uma reflexão crítica, a partir do olhar das pesquisadoras, acerca do que foi apresentado na Análise Formal, correlacionando cada tópico ao que foi discutido na literatura previamente apresentada. Aqui, é esperado que surjam novos pensamentos e ideias e que, além disso, haja construção de possíveis significados (Demo, 2001). Assim, considerando o estudo de Demo (2001), esta seção será construída sob a perspectiva de três pilares básicos: 1) Capacidade de entender o outro como ele gostaria de ser entendido; 2) Interpretação a partir de uma visão desconstruída e 3) Reconstrução crítica dos fenômenos analisados. Essa parte do trabalho será subdividida da seguinte maneira: Metodologias Ativas e Metodologia Ativa no UniCEUB; HA; IESC; TBL; Sinergismo entre IESC e HA; Docente.

Cabe destacar, ao leitor, que um novo subtópico surge nesse momento: o docente. Fez-se necessário uma reflexão em um tópico a parte, nesse momento, por observarmos que a atuação do professor em todo o processo, desde a implantação da metodologia ativa até o processo ensino-aprendizagem, torna-se um diferencial em vários momentos e etapas da graduação médica da instituição em análise.

\section{1. Metodologia Ativa e Metodologia ativa no UniCEUB}

Observamos que ao realizarmos a primeira pergunta aberta do GF "Qual a sua opinião sobre as metodologias ativas na graduação médica?" os alunos de todos os grupos mostraram-se confortáveis em expressar o que pensam sobre a metodologia ativa (MA) e em compararem com o método tradicional (MT) de ensino. Podemos dizer que quase todos os alunos participantes dos GF, se não todos, consideram a MA superior à MT nos seguintes pontos: melhor desenvolvimento da relação médico-paciente, maior proximidade entre professor e aluno, discussões cíclicas de diversos assuntos durante a graduação, de acordo com a proposta do aprendizado em espiral, busca ativa por conhecimento. Em contrapartida, na percepção dos discentes a MT mostra-se superior a MA quando comparamos o preparo dos alunos em matérias introdutórias do curso de medicina, tais como: farmacologia, histologia, anatomia e citologia. Os grupos 1 e 3 consideram que essa falha ocorre não porque a medicina, na instituição, se desenvolve em um modelo 
ativo de ensino, mas porque o UniCEUB não tem conseguido realizar uma implantação efetiva do ABP.

Para os alunos, muitos docentes e coordenadores das disciplinas dos 3 eixos IESC, HA e tutorial mostraram-se irredutíveis quanto a utilização de aulas expositivas dentro da ABP o que por vezes, para os discentes, prejudica a compreensão de conteúdos considerados básicos. Contudo, as disciplinas do core curriculum, que compõe a grade horária do curso durante o ciclo básico, são desenvolvidas de forma expositiva, na perspectiva do MT. Goldhaber (1973) considera que a MA desde a sua implantação carrega consigo problemas estruturais no ensino de matérias consideradas básicas, como já discutido na fundamentação teórica. Dessa forma, o problema no aprendizado dessas matérias não está relacionado direta ou exclusivamente à instituição, e sim ao método de ensino adotado pelo UniCEUB, o qual não visa ensinar através de aulas expositivas. Vale salientar, no entanto, que o questionamento dos discentes torna-se válido à medida em que observa-se o estudo desenvolvido por Sousa e Junior (2010), o qual apresenta a utilização de uma metodologia híbrida como uma possível solução do problema apresentado, tendo em vista que as disciplinas de base do curso, como anatomia e histologia, necessitam de outro tipo de abordagem, como a do método tradicional de ensino.

A segunda pergunta aberta "Qual a sua percepção sobre a aplicação da metodologia ativa no curso de medicina do UniCEUB?" levantou debates calorosos acerca da falha na implantação da MA na instituição. Os discentes mostraram-se inquietos e insatisfeitos ao discutirem a maneira como o método tem sido adotado nos três eixos principais IESC, HA e Tutorial. Apesar de todos os grupos considerarem que, dentro do eixo tutorial, a tutoria tem implantação adequada de acordo com a ABP, os grupos 1 e 3 afirmam que o morfofuncional, que também compõe o eixo e onde são ensinadas as matérias de base, não tem sido efetivo no processo ensino-aprendizagem, devido à falta de organização e de continuidade dos conteúdos abordados. Além disso, todos os grupos avaliaram o core curriculum como um eixo de ensino que não está bem articulado à proposta do curso de medicina nem pela forma como aborda os conteúdos e nem pelo método adotado em sua execução. Assim, a literatura defende que a ABP representa um desafio às instituições e que, para a efetividade da $M A$, é necessário que haja uma reformulação de pensamento dos docentes inseridos nessa nova realidade e que 
estes estejam abertos às mudanças no processo ensino-aprendizagem, lembrando, contudo, que o discente é o autor do seu próprio conhecimento (MERHY,1999).

\section{2. HA: a importância da semiologia, semiotécnica e profissionalismo para o médico em formação}

$\mathrm{Na}$ análise dos grupos, foi unanimidade a nítida assimetria que há entre os estudantes tanto de uma mesma turma, por estar dividida em subgrupos, quanto de turmas diferentes. O ciclo básico, mesmo tendo um cronograma, previsto no projeto pedagógico, a ser seguido pelos docentes, mostrou-se deficiente no que tange à preparação dos alunos para o ciclo clínico, de forma que alguns alunos enfrentam dificuldades nas atividades práticas nos hospitais por não terem tido um preparo semiotécnico adequado. Concluiu-se, na perspectiva dos discentes, que a diferença na conduta e na cobrança dos docentes de cada subgrupo, durante os dois primeiros anos de graduação, é o principal agente causal dessa assimetria. A insatisfação com relação à assimetria existente entre os subgrupos foi expressada pelos discentes não apenas por meio de um simples discurso queixoso, mas pela maneira agressiva e, em algum grau, ressentida de expressar as ideias, de modo que alguns alunos demonstraram que se sentiram "lesados" pelo fato de terem sido mal preparados. "Eu, no $1^{\circ}$ e no $2^{\circ}$ semestre, tava com uma professora, que digamos que ela tambem não sabia o que ela tava fazendo. $1^{\circ}$ ano eu não aprendi nada.......aí no $3^{\circ}$ e no $4^{\circ}$ já, os professores já estavam cobrando mais conhecimento.....aí ficava aquela cobranca de "nossa você chegou até aqui sem saber nada? Isso é culpa sua!" (Grupo 1).

Em contrapartida, segundo os grupos 1,3 e 4, o ciclo clínico tende a homogeneizar a turma, pois todos os alunos passam pelos mesmos rodízios, dentro das grandes especialidades médicas, durante o semestre, sendo que todos são cobrados de maneira equivalente pelos mesmos professores em cada rodízio. A padronização dos alunos é fundamental para que haja um crescimento da turma em conjunto, de modo que todos os discentes estejam em um mesmo "patamar" no processo ensino-aprendizagem e, assim, possa haver uma troca de experiências enriquecedoras nos cenários de prática. De acordo com Faria et al (2018), quando a assimetria predomina em detrimento da homogeneidade de uma turma, cria-se um meio propenso à competição. Essa competição representa um grande obstáculo 
dentro da graduação e limita, cada vez mais, a capacidade dos alunos em compreender a importância de um trabalho multidisciplinar, o qual é fundamental para a atuação do médico.

Em HA cirúrgicas, a proposta da aprendizagem em "espiral" foi alcançada com êxito, como relatado nos grupos 3 e 4, uma vez que os alunos tiveram o primeiro contato com as técnicas cirúrgicas no quinto semestre e no semestre seguinte revisaram o que já havia sido aprendido, porém, com maior grau de profundidade, relacionando a técnica com os procedimentos cirúrgicos. No quarto ano do curso, quando os alunos são inseridos no cenário de prática cirúrgica no hospital, mesmo que tenham desenvolvido habilidades técnicas para realizar o procedimento em um paciente, os docentes os acompanham em todo momento e trabalham, mais uma vez, todas as técnicas desenvolvidas desde o quinto semestre, alinhando o conhecimento já adquirido à uma prática real. Esse método de ensinoaprendizagem desenvolvido pelos docentes coaduna com a literatura, tendo em vista que Cezar et al (2010) defendem a ideia de que as escolas médicas devem ter um corpo docente capacitado que atue na supervisão dos alunos durante o decorrer do curso e que contribua para a consolidação do conhecimento.

No eixo de HA, a disciplina de Profissionalismo para os grupos 1, 3 e 4, foi importante principalmente durante o sexto semestre, em que o conteúdo central foi o Código de Ética Médica e onde puderam aprofundar o conhecimento acerca dos direitos e deveres do profissional médico. Os alunos estiveram mais próximos da realidade durante a atividade desenvolvida no CRM-DF (Conselho Regional de Medicina do Distrito Federal) e aprenderam, através da apresentação de casos, como se dá a supervisão do CRM sobre as denúncias para que haja o cumprimento da lei. Dessa forma, consideramos que um bom profissional médico não é apenas aquele que domina todos os conteúdos teóricos e as técnicas, mas que, além disso, saiba atuar de maneira ética no exercício da profissão. Além disso, os grupos 2, 5 e 6, consideraram que a disciplina de Profissionalismo permite debates e troca de experiências que podem ser enriquecedoras, dependendo da organização do docente, o que permite aos graduandos ampliar sua visão do processo saúdedoença, não limitando a prática médica apenas a uma patologia, mas aprendendo a reconhecer que por trás de uma doença há um paciente que precisa ser escutado, respeitado e bem tratado. Apesar disso, nos grupos 3 e 5 foi relatado que a falta de um cronograma reduz a potencialidade que a disciplina pode alcançar, de modo que 
a organização dos temas a serem debatidos com os docentes ao longo do semestre, permitiria um estudo prévio por parte dos discentes e, assim, discussões mais aprofundadas e um melhor aproveitamento da disciplina durante o curso. Profissionalismo, apesar das grandes limitações apontadas aqui e na Análise formal, é uma parte do processo ensino-aprendizagem fundamental para a graduação médica, pois possibilita que o estudante desenvolva habilidades afetivocomportamentais e aprenda como lidar com o paciente, como fortalecer a relação médico-paciente e como criar vínculos para que exerça uma medicina mais humana. Dessa forma, as pesquisadoras concordam com a maior parte dos discentes: o que falta a esse subeixo é organização e melhor preparo das atividades.

No terceiro semestre do curso, em que o tema abordado é "Saúde da criança", foi unanimidade entre os grupos o sinergismo que houve entre os três eixos principais: IESC, HA e Tutorial. Assim, como já discutido na análise formal, a semiologia e semiotécnica, desenvolvidas em HA, relacionavam-se com o conteúdo teórico discutido nos grupos de tutorial e ambos eram aplicados nas atividades de IESC 3 dentro do cenário de prática, tanto nas VD, como no acompanhamento da dinâmica do Centro de Saúde. Os benefícios dessa coesão entre os eixos de ensino para a formação médica encontram respaldo na literatura, tendo em vista que Melo et al (2017) e Rocha et al (2016) defendem em seus estudos a ideia de que os cursos na área da saúde, por estarem relacionados com o processo saúde-doença do homem, devem ocorrer dentro de um modelo de ensino que esteja sempre articulado e integrado.

Após análise formal o que foi possível observar, com relação ao eixo de HA, é que apesar das diferentes metodologias adotadas ao longos dos primeiros anos do curso, o que, de fato determinou as distintas definições dos alunos, em satisfatório ou não, foi baseado na organização do docente e na assimetria dos alunos. Foi possível notar que as queixas dos alunos se direcionaram a etapas do eixo e do curso em que os discentes são subdivididos em grupos e permanecem sob supervisão de um único docente: ciclo clínico e cirúrgica.

\section{3. IESC: a importância de um contato efetivo com uma Comunidade desde o início da graduação médica}


Os alunos do grupo 4 e 1 afirmam que entre os potencialidades do eixo de IESC, o contato com o paciente desde o início do curso possibilita um fortalecimento da relação médico-paciente e auxilia no desenvolvimento de habilidades, tais quais, empatia, escuta-ativa e paciência. Segundo Andrade et al (2001), a maioria dos alunos, durante as atividades práticas, demonstram atitudes positivas em respeitar os preceitos éticos da medicina, por exemplo, na abordagem de pacientes com baixa escolaridade que podem divergir da escolha terapêutica do médico e na escuta ativa de pacientes poliqueixosos. Em conformidade com o autor, os grupos afirmaram que o contato com a comunidade no cenário das atividades práticas favorece que os discentes vivenciem e aprendam a lidar e a respeitar diferentes culturas e classes sociais, o que contribui para um olhar mais humanizado do profissional de saúde para com o paciente. Foi exposto também, por todos os grupos, que as ações de saúde durante o primeiro ano da graduação são benéficas para o desenvolvimento acadêmico, uma vez que, nesse momento, é possível aplicar à realidade as ações de promoção de saúde e prevenção de agravos, após um levantamento territorial dos principais problemas de saúde da região, e, assim, ter uma resolutividade para a população do cenário em que os alunos estão inseridos. Esse processo coaduna com as ideias de Hora et al (2013) já expostas na fundamentação teórica, as quais defendem que a educação em saúde deve priorizar três etapas: processo ensinoserviço, humanização do atendimento e ampliação da prática da integralidade, princípio norteador do SUS, sendo que estas etapas devem se adequar às necessidades da população e ao fortalecimento do funcionamento do SUS.

Foi unanimidade entre os grupos a efetividade em IESC 3 , ao passo que nos grupos 1, 2, 3, 4 e 5 o IESC 5 também foi elogiado devido à organização do docente e ao êxito obtido durante o semestre na disciplina. Contudo, no grupo 1 houve uma divergência quanto à avaliação do IESC 5 entre os alunos de subgrupos diferentes, ou seja, acompanhados por diferentes professores. Um determinado subgrupo afirmou ter estudado e discutido a política de saúde do adolescente em sala e ter organizado todas as atividades a serem realizadas na escola, a qual foi proveitosa e de grande aprendizado para os graduandos. Em contrapartida, o outro subgrupo relatou que as discussões sobre a política de saúde não eram efetivas e que as atividades práticas não foram bem planejadas. Dessa forma, percebe-se uma heterogeneidade entre alunos de uma mesma turma devido a uma discrepância na conduta e orientação por parte do docente. 
Uma outra questão discutida por todos os grupos foi a problematização que ocorre após a VD. Os alunos relataram que da forma como era realizada a problematização, até $1 / 2017$, não era eficaz pois, muitas vezes, o problema era estudado e pensado apenas pelo trio que havia realizado a VD e o professor. No entanto, após a adoção do novo método de ensino, o TBL, a forma de discussão tornou-se mais rica e mais direcionada o que favorece a elaboração de PTS mais eficientes. Segundo Xavier et al (2014), a problematização tem como base a "açãoreflexão-ação", de modo que os alunos conseguem, após o contato com a realidade, fazer um levantamento bibliográfico e criar métodos de intervenção, a qual seja viável à realidade daquela comunidade.

Com relação ao projeto terapêutico singular o grupo 1 afirmou que não houve, no início da graduação, um preparo dos alunos para aprenderem a elaborar um PTS e que isso deixou uma lacuna dentro das atividades práticas desenvolvidas com as famílias. Os grupos apontaram que não saber elaborar um PTS inviabiliza intervenções mais eficientes nas VD. A importância de se entender como é construído e aplicado um PTS é reforçada na literatura por Ritt (2014), que afirma que o projeto deve ser construído após um debate diversificado e multidisciplinar sobre as intervenções que se pretende adotar para uma família, considerando cada indivíduo de maneira holística e com suas particularidades.

Uma das atividades práticas de IESC que gerou grande repercussão entre os estudantes foi a VD. Os alunos pontuaram como positivo a presença de um docente (grupo 5), a promoção e prevenção de agravos por meio da elaboração e implantação de PTS e por meio de ações de saúde nos diversos cenários (grupos 3 e 5), o supervisor de saúde ser vinculado ao cenário de saúde ( grupos 1 e 4), o acompanhamento da mesma família por até 3 anos, uma vez que possibilita a criação de vínculo (grupo 2). Nesse contexto, durante os debates, podemos observar que os discentes sentem-se realizados em perceber que, ainda que em pequena escala, podem contribuir para melhoria da saúde da comunidade, além de poderem desenvolver e aprimorar diversas habilidades, o que se coaduna com Mourão (2010), Silva et al (2016) e Pereira (2015). Em contrapartida, os alunos consideraram desafios vinculados à VD o fato de não terem contato com toda equipe de saúde, principalmente o MFC (3 e 4), a desorganização na marcação/confirmação das VD junto às famílias acompanhadas (2, 3 e 6), a impossibilidade de realização de exames físicos (grupo 2 e 6), o que demonstra a desorganização da instituição, dos 
cenários de saúde e a assimetria entre os grupos o que é altamente prejudicial a formação dos discentes, além de ser um potencializador de estresse (Santos et al, 2015).

\section{4. TBL - Team-based Learning (Aprendizagem Baseada em equipes)}

O TBL é um tipo de metodologia ativa e foi adotado durante o ano de 2017, no eixo de IESC. Os GF foram realizados em um momento de implantação do método e dessa forma consideramos que não é possível, de fato, entender inteiramente a perspectiva dos discentes sobre o método, uma vez que ainda existiam dificuldades em entender os motivos da implantação e a forma de funcionamento do TBL.

Apesar da literatura, ao descrever o método, prever que ele pode ser explicado e entendido a medida em que são realizadas as atividades individuais e em grupo do TBL (Bollela, 2014), o que foi possível observar é que os discentes, principalmente os que participaram dos grupos 1, 2 e 3, não conseguiam compreender como o método funcionava e nem a finalidade dele. Dessa forma, entende-se, como uma falha de implantação do método o despreparo de discentes e de docentes com relação ao funcionamento, etapas a serem seguidas e realização da nova metodologia. Um ponto exposto por todos os grupos e com demonstração de grande insatisfação e mesmo raiva é a falta de colaboração do docente ao não enviar o material de referência para o TBL com pelo menos uma semana de antecedência. Para os discentes isso acarreta em sobrecarga de estudo e em mais fatores de estresse ao longo do semestre o que acaba dificultando o aprendizado.

Outro problema, levantado pelos alunos, foi a forma como os conteúdos dos TBL's eram cobrados nas avaliações, de forma que foi questionado o processo de aprendizagem mediante a cobrança de questões que não exigiam raciocínio, mas sim, a habilidade de decorar. Um ponto questionado por nós, pesquisadoras, é a última etapa do TBL descrita nos trabalhos de Bollela (2014) e Krug (2016) denominadas de casos clínicos ou de aplicação de conceitos, respectivamente. Essa etapa tem sido realizada em IESCs específicos, como o IESC V, mas acreditamos que, sendo cumprido em todos os semestres, seria um momento de compreensão de todo o processo que foi realizado anteriormente e promoveria fixação do conteúdo por possibilitar a aplicação do que foi estudado e debatido com a realidade 
em que o discente é inserido. Compreendemos que essa etapa foi realizada na avaliação semestral do grupo 2, momento em que os alunos observaram a junção de todas as atividades que deveriam ser discutidas e expostas na prova a partir de casos clínicos ou situações reais.

Diante do exposto sobre o método TBL aplicado no UniCEUB o que é possível destacar é: 1) É necessário melhor orientação dos discentes quanto ao método aplicado em sala de aula e às etapas que o compõe; 2) É importante que os docentes percebam que, independente do método aplicado, as avaliações vão exigir o mínimo de raciocínio crítico, caso contrário os alunos continuarão não se dedicando individualmente e nem em grupo; 3) É importante que haja uma discussão final aproximando as atividades dos TBL's com a realidade que os alunos irão vivenciar, ou já vivenciaram, na prática; 4) É fundamental, para o processo de aprendizagem e de organização individual do aluno, que os materiais de referência para os TBL's sejam enviados com antecedência, se possível no início do semestre.

\section{5. Sinergismo entre IESC e HA: a necessidade de que as disciplinas sejam integradas para o fortalecimento da relação médico-paciente}

Os alunos foram questionados acerca da relação entre os eixos de IESC e HA e de como um eixo poderia contribuir para o outro. Para os discentes IESC contribui para o desenvolvimento da relação médico-paciente, para o entendimento do que é a escuta ativa, para percepção do paciente como um indivíduo holístico e altamente influenciado pelo meio em que está inserido, para percepção de realidades distintas da que o estudante de medicina está inserido. Ao passo que HA prepara o estudante para a prática a medida em que se estuda a semiologia e aprende a técnica que deve ser aplicada na investigação de cada grande sistema. Nesse sentido podemos perceber que um eixo depende do outro quando o objetivo é desenvolver um médico mais humano, um médico cujo foco é o paciente e não a doença, um médico que investiga a origem da causa ao invés de ter como foco de tratamento apenas a doença. Essas características fazem parte da proposta da MA, conforme trabalhado por Teófilo; Santos; Baduy (2017), além de serem condizentes com as propostas das DCN (2001) e com o previsto no projeto pedagógico do curso de medicina (UniCEUB, 2001, p. 12 e 13). 
Há, no entanto, problemas estruturais relacionados à aplicação de um eixo no outro. Dois grupos, grupo 2 e grupo 6 relataram que em atividades de VD, relacionadas ao eixo de IESC, foram impedidos, pelos docentes, de aplicar os conhecimentos semiotécnicos que aprenderam em HA, fato que não foi observado nos demais grupos. Isso é uma contradição de acordo com a literatura e com o próprio projeto pedagógico, uma vez que durante a VD muitos alunos identificam problemas que não haviam sido observados em outros momentos nos serviços de saúde. Além disso, o acompanhamento de algumas doenças, como hipertensão arterial, implicam na aplicação de habilidades desenvolvidas em HA, como aferição de pressão. Fica claro, portanto, que ao impedir um aluno de aplicar a habilidade desenvolvida em um eixo em outro prejudica tanto a população assistida como o próprio graduando. Nesse sentido, deve-se considerar estabelecer com os alunos os limites de todos os exames que podem ser realizados na residência dos usuários do SUS acompanhados na VD e não impedi-los de realizá-los.

\section{6. Docente: a importância da organização e do preparo do corpo docente para a metodologia de ensino}

Após a análise formal o que foi possível observar em relação ao eixo de HA é que, apesar das diferentes metodologias adotadas ao longos dos primeiros anos do curso, o que de fato determinou a satisfação ou insatisfação dos alunos foi a organização dos docentes e a padronização da turma ao final de cada semestre. Notou-se que as queixas dos alunos se direcionaram às etapas do curso em que os discentes são subdivididos em grupos e permanecem sob supervisão de um único docente, como acontece durante todo o ciclo básico e na disciplina de cirurgia no primeiro ano do ciclo clínico. O fato de cada professor ter métodos de ensino, avaliação e cobrança diferentes, faz com que surja uma assimetria no processo ensino-aprendizagem dos graduandos, tendo em vista que, como exposto na análise formal, um grupo aprendia mais que outro, tanto quantitativamente, quanto qualitativamente. Essa falta de homogeneidade entre os alunos devido à discrepância entre os docentes, foi vista não só no eixo de HA, como também no eixo de IESC, como já discutido anteriormente. Dessa forma, pode-se concluir que a heterogeneidade entre os alunos só será minimizada quando houver homogeneidade entre os professores, os quais precisam ser igualmente preparados 
para o método de ensino da instituição em que atuam, assim como a ideia defendida por Costa, Cardoso e Costa (2012, p. 503):

É necessário repensar e promover uma reflexão conjunta sobre as características e atitudes necessárias aos docentes de Medicina, pois as características de um bom professor se relacionam à sua capacidade de adequação ao novo modelo de educação e ensino.

O preparo do corpo docente no eixo de HA e IESC no terceiro semestre do curso é um exemplo de que a organização de um cronograma detalhado para a disciplina, aliada ao preparo dos professores para seguir o roteiro das atividades e tendo à frente um coordenador que faça ser cumprido tudo o que foi proposto, faz com que toda a turma, independente de estar subdividida, conclua o semestre tendo aprendido o mínimo necessário que todo aluno, naquele semestre, deve aprender. Dessa forma, ser um bom professor, vai além do domínio teórico acerca de um determinado tema, sendo fundamental saber exigir dos alunos, mas também aceitar ser exigido e cobrado por parte de um docente coordenador. Além disso, os coordenadores de cada eixo também devem ter competência técnico-profissional e saber como cobrar e manter o seu grupo de professores organizado e alinhado com a proposta da disciplina e, sobretudo, com o modelo de ensino. Aliado a isso, Costa et al (2012, p. 504) propõem que planejar e estruturar o corpo docente para o curso de medicina é um dos pontos-chave para se aperfeiçoar a docência médica, ponto este que está diretamente relacionado ao papel de um bom coordenador:

Um dos itens primordiais para o aprimoramento da docência médica é
planejar uma formação pedagógica que integre experiências e vivências
docentes com a discussão e o debate de princípios teóricos de educação,
oferecendo aos professores uma luz que os ajude a analisar criticamente
sua ação e experiências docentes, para que eles consigam encontrar novos
e melhores caminhos para seu trabalho.

\section{Considerações Finais}

De acordo com os objetivos propostos em avaliar, a partir da percepção dos estudantes de medicina da instituição, o impacto das disciplinas de IESC e HA para a capacitação dos graduandos e as atividades desenvolvidas na MA, o presente estudo buscou obter esses dados através de uma pesquisa qualitativa. A avaliação das limitações e potencialidades das atividades práticas durante o curso de medicina, desenvolvidas em IESC e HA, foi realizada a partir de GF em seis turmas distintas. Diante disso, após a transcrição e análise dos dados, e considerando os aspectos positivos e negativos dos eixos, a partir da visão dos discentes dos GF, e 
as sugestões propostas pelos mesmos, aplicamos o método de Thompson (1995), reinterpretado por Demo (2001), da Hermenêutica de profundidade. Essa metodologia permitiu uma análise crítico-reflexiva dos GF associada a uma interpretação dinâmica que, por considerar o ambiente e o contexto sócio-histórico em que a pesquisa se desenvolveu, permitiu uma avaliação mais efetiva da situação estudada.

Dessa forma, conclui-se que a MA quando comparada ao MT, apresenta algumas limitações quando se analisa a efetividade das disciplinas básicas do curso desenvolvidas nos diferentes métodos. A anatomia, a farmacologia e a histologia, por exemplo, foram matérias consideradas essenciais e que, para os alunos, deixaram a desejar quanto ao conteúdo aprendido devido à falta de aulas ministradas pelos docentes de maneira expositiva, como ocorre no MT. Além disso, a heterogeneidade percebida entre as turmas de medicina foi outro fator relevante no estudo, sendo que em todos os GF os alunos relatam que a subdivisão da turma, com docentes diferentes para cada grupo, cria uma assimetria quanto ao conteúdo ministrado e à forma como é ensinado, tendo em vista que a cobrança dos docentes às vezes é diferente e a habilidade em ensinar também. Vale ressaltar que há elogios ao corpo docente e a certeza de que há na instituição professores empenhados e que lutam por uma formação de qualidade, assumindo o papel de orientador e facilitador do conhecimento. No entanto, a falta de homogeneidade do corpo docente muitas vezes é o que tem prejudicado o crescimento simétrico da turma.

Por fim, conclui-se também que o sinergismo entre as disciplinas de IESC e HA proposto na metodologia de ensino não é inteiramente, segundo a visão dos alunos, eficaz na instituição. Pôde-se inferir que as habilidades semiológicas e semiotécnicas desenvolvidas em HA contribuem com as atividades práticas de IESC, principalmente nos atendimentos nas UBS e VD, e, no entanto, as atividades de IESC acrescentam pouco nas práticas de HA. Entretanto, na conclusão das análises, foi possível observar que, apesar de todas as limitações e dificuldades enfrentadas durante as atividades na graduação, de algum modo, os eixos de IESC e HA se complementam e trazem benefícios um ao outro, pois permitem a aquisição de habilidades tanto técnicas quanto empáticas, mesmo que os estudantes não percebam esse fato. Isso pôde ser observado, por meio de relatos de alguns GF de que IESC, através das VD, permite desenvolver habilidades de empatia, escuta ativa 
e paciência, as quais são fundamentais não só para aprimorar as atividades de HA durante a graduação, mas para a construção de médicos mais humanos. 


\section{Referências}

ANDRADE, S. C. et al. Avaliação do desenvolvimento de atitudes humanísticas na graduação médica. Revista Brasileira de Educação Médica. Rio de Janeiro, v. 35, n. 4,p. 517-525, oct/dez. 2011.

AGUIAR, A.C. Implementando as novas diretrizes curriculares para a educação médica: o que nos ensina o caso de Harvard? Interface - Comunicação, Saúde, Educação.

Botucatu, v. 5, n. 8, p. 161-166. 2011. http://dx.doi.org/10.1590/S1414-32832001000100020

ALMEIDA, E.G; BATISTA, N.A. Desempenho Docente no Contexto PBL: Essência para Aprendizagem e Formação Médica. Revista Brasileira de Educação Médica. Brasília, v. 37, n. 2, p. 192-201. 2013

BARROS, N.F. e LOURENCO, L.C.A. O ensino da saúde coletiva no método de aprendizagem baseado em problemas: uma experiência da Faculdade de Medicina de Marília. Revista brasileira de educação médica [online]. São Paulo, v.30, n.3, p.136146. 2006

BERBEL, N.A.N. As metodologias ativas e a promoção da autonomia de estudantes. Semina: Ciências Sociais e Humanas. Londrina, v. 32, n. 1, p. 25-40. 2011

BORGES, C.D. Aplicações da técnica do grupo focal: fundamentos metodológicos, potencialidades e limites. Revista da SPAGESP - Sociedade de Psicoterapias Analíticas Grupais do Estado de São Paulo. Ribeirão Preto, v. 6, n. 1, p. 74-80, jan/jun. 2005.

BORGES, C.D. e SANTOS, M.A. dos. Aplicações da técnica do grupo focal: fundamentos metodológicos, potencialidades e limites.Rev. SPAGESP,Ribeirão Preto, v.6, n.1, 2005.

BOLLELA, V.R. Aprendizagem baseada em equipes: da teoria à prática. Medicina (Ribeirão Preto). Ribeirão Preto, v. 47, n. 3, p. 293-300. 2014. Disponível:

http://www.revistas.usp.br/rmrp/article/view/86618/89548

Brasil. Ministério da Educação. Conselho Nacional de Educação. Câmara de Educação Superior. Resolução CNE/CES no4 de 7 de novembro de 2001. Diário Oficial da União. Brasília, 9 nov. 2001; Seção 1, p.2.

Brasil. Ministério da Saúde. Promed-Programa de Incentivo às Mudanças Curriculares para as Escolas Médicas. Brasília: Ministério da Saúde; 2002. Disponível em :< http:// www.saude.gov.br/sgte>.Acesso em 20 abr. 2017.

CAVALHEIRO, M.T.P; GUIMARÃES, A.L. Formação para o SUS e os desafios da integração ensino serviço. Caderno FNEPAS. Campinas, v. 1, p. 19-27. 2011.

CENTRO UNIVERSITARIO DE BRASILIA. Projeto Pedagogico do curso de Medicina. Brasilia. UniCEUB, 2001. Disponivel em: <https://mailattachment.googleusercontent.com/attachment/u/0/?ui $=2 \& \mathrm{ik}=06 \mathrm{ae} 3 \mathrm{ccdf} 5 \& \mathrm{view}=\mathrm{att} \& \mathrm{th}=15 \mathrm{bd}$

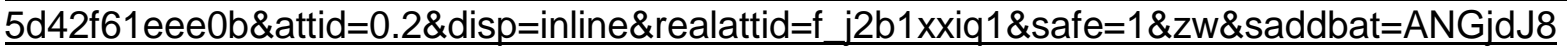
QUKWoKgw3xgnvJLd706IIxqc12gw7TewPJHH0tXRWODrun8vK7gw1u67epk zEzLcrNkHAt2ZyMaHM6kXWK1c2wCmPUK1bPOYDHdGqOvRqAEhb Lfbtp0vUyZFE9HDQ22wiR99yZPswOImEp7KIWGcS517OYRo9aqKndx7BzyHeXah4yqUh24YO ebFCRF KsitidHuMj2jzpXjgrEJfo53 9JRi2ubyqph64qJ NkDa6EoAUliHkMHyntH0a1ltXDL6i7gK2B5kmkNGKb6KfJi vco5SgzyooNWYw-sqgngvnAul5AJBE9Dy6p50THj-tdlp7dqdbma 1b- 
wPOtjKYXTaHqoBi5aJcYTrB lu74W2bVOMb1n9mBA7Jm6azyiFklmCJw7b9fgVr3Dn3LVxO F5CRhLSkLTi2Uu3OT8NC3KDhBLU8kvC12afG4BoDbF6p75kcrrLMISGpU3OMI7nhNUzgdB $\mathrm{P}-$

13w5PNr E66FIECTUMcfcIFVtZWYPxTQxs2nt0NYQ90o7C7nDYWizhtzp uRZjdsPT8XGgu wl7GxS1Xpd6bfHIt YQORiYADoiTN9CljCxeYiNoBK6UP7P2Ryv7Fu9ZqHZ73p-

Xf vaDrcZBow7OvZdXVv5bavqimKZjf4wk zD>. Acesso em 4 maio 2017.

CEZAR, P.H.N. et al. Transição paradigmática na educação médica: um olhar construtivista dirigido à aprendizagem baseada em problemas. Revista Brasileira de Educação Médica. Rio de Janeiro, v. 34, n. 2, p. 298-303, jun. 2010.

CHIRELLI, M.Q; MISHIMA, S.M. A formação do enfermeiro crítico-reflexivo no curso de enfermagem da Faculdade de Medicina de Marília - FAMEMA. Revista Latino-Americana de Enfermagem. Marília, v. 11, n. 5, p.574-584, out. 2003.

COLARES, M.F.A. et al. Construção de um instrumento para avaliação das atitudes de estudantes de Medicina frente a aspectos relevantes da prática médica. Revista Brasileira de Educação Médica. Rio de Janeiro, v. 26, n. 3, p. 194-203, set/dez. 2002.

COSTA, N.M.S.C; CARDOSO, C.G.L.V; COSTA, D.C. Concepções sobre o Bom Professor de Medicina. Revista Brasileira de Educação Médica. Brasília, v. 36, n. 4, p. 499-505. 2012. Disponível: http://www.scielo.br/pdf/rbem/v36n4/08.pdf

DEMO, P. Pesquisa e informação qualitativa: aportes metodológicos. Campinas, SP: Papirus, 2001. (Coleção Papirus Educação).

FARIA, L. et al. Integração ensino-serviço-comunidade nos cenários de práticas na formação interdisciplinar em Saúde: uma experiência do Programa de Educação pelo Trabalho para a Saúde (PET-Saúde) no sul da Bahia, Brasil. Interface - Comunicação, Saúde, Educação. Botucatu, 2018

FRANCO, C.A.G.S; CUBAS, M.R; FRANCO, R.S. Currículo de medicina e as competências propostas pelas diretrizes curriculares. Revista Brasileira de Educação Médica. Rio de Janeiro, v. 38, n. 2, p.221-230, jun. 2014.

GATTI, B.A. Grupo focal na pesquisa em clinicas sociais e humanas. Brasília: Líber Livro Editora, 2005.

GOLDHABER, S.Z. Medical Education: Harvard Reverts to Tradition. Science. Washington DC, v. 181, n. 4104, p. 1027-1032. 1973. DOI: 10.1126/science.181.4104.1027.1973

GOMES, A.P; REGO, S. Transformação da educação médica: é possível formar um novo médico a partir de mudanças no método de ensino-aprendizagem? Revista Brasileira de Educação Médica. Rio de Janeiro, v. 35, n. 4, p. 557-566. 2011.

HORA, D.L. et al. Propostas inovadoras na formação do profissional para osistema único de saúde. Trabalho Educacao Saúde, Rio de Janeiro, v. 11, n.3, p. 471-486, set./dez. 2013

KEBIAN, L.V.A; ACIOLI, S. A visita domiciliar de enfermeiros e agentes comunitários de saúde da Estratégia Saúde da Família. Revista Eletrônica de Enfermagem. Goiânia, v. 16, n. 1, p. 161-169. 2014.

KOGA JÚNIOR, M.et al. Percepções de estudantes de medicina sobre competências pedagógicas no contexto da Aprendizagem Baseada em Problemas de universidade da 
Amazônia brasileira. Atas CIAIQ2016.Investigação Qualitativa em Educação. Amapá.V. 1, p. 260-269, 2016.

KAHWAGE NETO,S.L. et al. O Ensino de Habilidades Clínicas e a Aplicabilidade de um Guia Simplificado de Exame Físico na Graduação de Medicina. Revista brasileira de educação médica[online].Pará, v.41, n.2, p.299-309. 2017

KRUG, R.R. etal. O "Bê-Á-Bá" da Aprendizagem Baseada em Equipe. Revista Brasileira de Educação Médica. Florianópolis, n.40, v.4, p. 602-620. 2016

MERHY, E.E. Apostando em projetos terapêuticos cuidadores: desafios para a mudança da escola médico ou utilizando-se da produção dos projetos terapêuticos em saúde como dispositivo de transformação das práticas de ensino-aprendizagem que definem os perfis profissionais dos médicos. Revista Ciência \&amp; Saúde Coletiva. Rio de Janeiro, v. 10, n. 5, p. 13-17. 1999.

MELO, N.B. et al. Metodologia da Problematização e Aprendizagem Baseada em Problemas na Odontologia: análise bibliométrica dos trabalhos apresentados nas Reuniões da SBPqO.

Revista da ABENO. Londrina, v. 17, n. 2, p. 60-67. 2017.

MORGAN, D. L. The focus group guide-book. Thousand Oaks, CA: Sage, 1998

MOURÃO, S.M. et al. A visita domiciliar como instrumento para a promoção de práticas de higiene: uma revisão bibliográfica. SANARE - Revista de Políticas Públicas. Sobral, v. 9, n. 2, p. 86-92. 2010.

OZÓRIO NETO, J. et al. Aprendizagem baseada em problemas: o mito e a realidade. Cadernos UniFOA. Volta Redonda (RJ), v. 6, n. 16, p. 79-84, ago. 2011.

OLIVEIRA, N.A. et al. Mudanças curriculares no ensino médico brasileiro: um debate crucial no contexto do Promed. Revista Brasileira de Educação Médica. Rio de Janeiro, v. 32, n. 3, p.333-346, set. 2008.

PASQUALINI, B. et al.A aprendizagem baseada em problemas como foco da pesquisa nos cursos de medicina. Revista Uniplac. Lages,v. 4, n. 1. 2016.

PEREIRA, M.Q.S. et al. A visão do estudante de medicina do primeiro período diante da visita domiciliar. In: Health and Environment World Congress, 15., 2015, Porto. Anais... Porto, 2015. p. 380-383.

RESSEL, L.B.; BECK, C.L.C.; GUALDA, D.M.R.; HOFFMANN, I.C.; SILVA, R.M.; SEHEM, G.D.; O uso do grupo focal em pesquisa qualitativa. Texto Contexto Enfermagem, v.17, n.4, p. $779-86,2008$.

RITT, P.A.Q. Projeto Terapêutico Singular. TCC (especialização) - Universidade Federal de Santa Catarina. Centro de Ciências da Saúde. Programa de Pós-graduação em Enfermagem. Linhas de Cuidado em Atenção Psicossocial. Florianópolis, 2014.

ROCHA, J.S. et al. O uso da aprendizagem baseada em problemas na Odontologia: uma revisão crítica da literatura. Revista da ABENO. Londrina, v. 16, n. 1, p. 25-38. 2016. 
ROMANHOLI, R.M.Z; CYRINO, E.G. A visita domiciliar na formação de médicos: da concepção ao desafio do fazer. Interface - Comunicação, Saúde, Educação. Botucatu, v. 16, n. 42, p.693-705, set. 2012.

SANTANA, J.C.B. et al. Visita domiciliar dos agentes comunitários de saúde no planejamento das ações das estratégias da saúde da família: avanços e desafios. Enfermagem Revista. Belo Horizonte, v. 18, n. 2, p. 18-28. 2015.

SANTOS, B.E.F. et al. Avaliação discente sobre interação ensino, serviços e comunidade em equipes de saúde integradas ao Programa Mais Médicos em estado da Amazônia.

Revista Tempus - Actas de Saúde Coletiva. Brasília, v. 9, n. 4, p. 123-136, dez. 2015.

SCHREIBER, M.Trauma e Dor nas Costas: uma abordagem da Metodologia de

Aprendizagem Ativa. 2015. 54f. Dissertação - Centro de Ciências Biológicas e da Saúde, Pontifícia Universidade Católica do Rio de Janeiro, Rio de Janeiro. 2015.

SENA, R.R. et al. O cuidado no trabalho em saúde: implicações para a formação de enfermeiros. Interface (Botucatu) [online]. Botucatu, v.12, n.24, p.23-34. 2008

SILVA, I.S. et al. VISITA DOMICILIAR: ESTRATÉGIA PARA A PROMOÇÃODA SAÚDE DE PACIENTES CRÔNICOS. Revista de Enfermagem. FW, v.12, n. 12, p.88-99. 2016

SIMÕES, C.S. Erro médico: um perfil do profissional na Bahia. 2014. 31f. Dissertação Universidade Federal da Bahia, Salvador. 2014.

SILVA, J.; MAGALHÃES, M.C.C.; RESENDE, T.I.M. Adolescencia e a formação do profissional de medicina. 2018

SIQUEIRA, J.E. A evolução científica e tecnológica, o aumento dos custos em saúde e a questão da universalidade do acesso. Revista Bioética. Brasília, v. 5, n. 1, p. 41-48. 1997.

SOUSA, S.O; SCHLUNZEN JUNIOR, K. Aprendizagem Baseada em Problemas Aplicada à Formação Docente para o Uso das Tecnologias. In: Congresso Internacional - PBL 2010, 2010, São

Paulo, SP. Anais... São Paulo: PBL 2010, 2010. Disponível:

http://each.uspnet.usp.br/pbl2010/trabs/trabalhos/TC0276-1.pdf . Acesso em 23/08/2018

SOUZA, C.F.D. et al. O Impacto da Mudança do Processo de Ensino-Aprendizagem Tradicional para a Metodologia Ativa: Um Relato de Experiência. Revista UNIABEU. Belford Roxo, v. 9, n. 23, p. 162-177, set/dez. 2016.

SOUZA, C.S; IGLESIAS, A.G; PAZIN FILHO, A. Estratégias inovadoras para métodos de ensino tradicionais - aspectos gerais. Medicina (Ribeirão Preto). Ribeirão Preto, v. 47, n. 3, p. 284-292, jul/set. 2014.

SOUZA, L.J.Resenha.Bolema vol.30 no.56 Rio Claro set. /dez. 2016.

SOUZA, S.C; DOURADO, L. Aprendizagem Baseada em Problemas (Abp): Um Método de Aprendizagem Inovador para o Ensino Educativo. Holos. Natal, v. 5, n. 31. 2015. https://doi.org/10.15628/holos.2015.2880

TEÓFILO, T.J.S; SANTOS, N.L.P; BADUY, R.S. Apostas de mudança na educação médica: trajetórias de uma escola de medicina. Interface. Botucatu. V. 21,n. 60, p. 177-88,2017. 
THOMPSON, Ideologia e cultura moderna: teoria social crítica na era dos meios de comunicação de massa. Rio de Janeiro: Vozes, 1995.

-VERONESE, M.V.; GUARESCHI,P.A. Hermenêutica de Profundidade na pesquisa Ciências Sociais Unisinos, v.42, n.2, p.85-93, maio/ago 2006

VIEIRA, M.N.C.M; PINTO, M.P.P.A Metodologia da Problematização (MP) como estratégia de integração ensino-serviço em cursos de graduação na área da saúde. Medicina (Ribeirão Preto). Ribeirão Preto, v. 48, n. 3, p. 241-248. 2015.

VONBANK, A. et al. Toward a more professional and practical medical education: a novel Central European approach. Advances in Medical Education and Practice. [s.I.], v. 15, n. 6, p. 459-467, jun. 2015.

XAVIER, L.N. et al.Analisando as metodologias ativas na formação dos profissionais de saúde: uma revisão integrativa. SANARE - Revista de Políticas Públicas. Sobral, v. 13, n. 1, jan/jun. 2014.

ZULJAN, M.V et al. Didactic competencies of teachers from the learner's viewpoint.

Educational studies, 2012, n.38, v.1, p.51-62. 2012 


\section{APÊNDICE A-Perguntas Norteadoras}

Tabela 1- perguntas norteadoras para realização do grupo focal (p.15)

\begin{tabular}{|c|c|}
\hline \multirow[t]{2}{*}{ Perguntas de abertura } & $\begin{array}{l}\text { 1) Qual a sua opinião sobre as metodologias ativas } \\
\text { na graduação médica? }\end{array}$ \\
\hline & $\begin{array}{l}\text { 2) Qual a sua percepção sobre a aplicação da } \\
\text { metodologia ativa no curso de medicina do } \\
\text { UniCEUB? }\end{array}$ \\
\hline \multirow[t]{3}{*}{$\begin{array}{l}\text { Perguntas } \\
\text { de desenvolvimento temático }\end{array}$} & $\begin{array}{l}\text { 1) Na sua visão de discente, quais habilidades } \\
\text { devem ser desenvolvidas durante a graduação } \\
\text { médica para favorecer o processo ensino- } \\
\text { aprendizagem e a atuação profissional? }\end{array}$ \\
\hline & $\begin{array}{l}\text { 2) Na sua percepção de aluno, como as atividades } \\
\text { práticas desenvolvidas em IESC e HA refletem no } \\
\text { seu desenvolvimento acadêmico? }\end{array}$ \\
\hline & $\begin{array}{l}\text { 3) Para você, qual a relação entre as atividades } \\
\text { propostas nos eixos de IESC e HA? }\end{array}$ \\
\hline Pergunta Finalizadora & $\begin{array}{l}\text { 1) Como você considera que os resultados deste } \\
\text { estudo possam contribuir para a instituição de } \\
\text { ensino, discentes e docentes? }\end{array}$ \\
\hline
\end{tabular}

Fonte: Elaborado pelas pesquisadoras 
APÊNDICE B - Ordem dos grupos Focais e relação dos conteúdos estudados em cada semestre.

Tabela 2: Relação Turma- Grupo focal (p. 22)

\begin{tabular}{|l|l|}
\hline Turma & Grupo focal \\
\hline Turma 4 & Grupo 1 \\
\hline Turma 5 & Grupo 2 \\
\hline Turma 2 & Grupo 3 \\
\hline Turma 3 & Grupo 4 \\
\hline Turma 6 & Grupo 5 \\
\hline Turma 7 & Grupo 6 \\
\hline Turmas 2, 3, 4, 5 e 6 & Grupo final \\
\hline
\end{tabular}

Fonte: Elaborado pelas pesquisadoras

Tabela 3: Relação entre semestre cursado em IESC e a matéria abordada (p. 22) 


\begin{tabular}{|l|l|}
\hline IESC I & SUS \\
\hline IESC II & SUS \\
\hline IESC III & Saúde da criança \\
\hline IESC IV & Saúde da mulher \\
\hline IESC V & Saúde do adolescente \\
\hline IESC VI & Saúde do idoso \\
\hline IESC VII & Saúde do trabalhador e saúde do homem \\
\hline IESC VIII & Gestão e planejamento em saúde \\
\hline
\end{tabular}

Fonte: Elaborado pelas pesquisadoras e baseado nas descrições presentes no projeto pedagógico do curso de medicina e nos títulos dados ao demais IESC disponíveis no espaço aluno.

Tabela 4 Relação entre os anos da graduação médica e o conteúdo abordado em cada ciclo de aprendizagem (p. 22)

\begin{tabular}{|c|c|c|c|}
\hline $1^{\circ}$ e $2^{\circ}$ ano & Ciclo básico & Dentro do UniCEUB & $\begin{array}{l}\text { Aprender a fazer } \\
\text { anamnese e exame } \\
\text { físico }\end{array}$ \\
\hline $3^{\circ}$ ano & Ciclo clínico & $\begin{array}{lr}\text { Rodízio } & \text { das } \\
\text { grandes áreas no } \\
\text { hospital } \\
\text { médica, } \\
\text { pediatinica } \\
\text { geral) }\end{array}$ & $\begin{array}{l}\text { Colher } \mathrm{HC} \text { do } \\
\text { paciente de forma } \\
\text { direcionada }\end{array}$ \\
\hline $4^{\circ}$ ano & Ciclo clínico & $\begin{array}{ll}\text { Rodizio } & \text { das } \\
\text { grandes áreas no } \\
\text { hospital }\end{array}$ & $\begin{array}{l}\text { Atendimento } \\
\text { completo } \\
\text { supervisionado }\end{array}$ \\
\hline $5^{\circ}$ e $6^{\circ}$ ano & Internato & $\begin{array}{ll}\text { Rodizio } & \text { nas } \\
\text { grandes áreas } & \end{array}$ & $\begin{array}{l}\text { Atendimento } \\
\text { supervisionado nos } \\
\text { hospitais }\end{array}$ \\
\hline
\end{tabular}

Fonte: Elaborado pelas pesquisadoras tendo como base descrições do projeto pedagógico e espaço aluno 


\author{
ANEXO A- TCLE \\ Termo de Consentimento Livre e Esclarecido - TCLE \\ “Análise comparativa sobre a percepção dos estudantes de medicina acerca do \\ impacto das disciplinas de IESC e HA no contexto de atividades práticas \\ durante a graduação" \\ UniCEUB \\ Pesquisador(a) responsável: Tania Inessa Martins de Resende \\ Pesquisadoras assistentes [alunas de graduação]: Natália Mariana Diógenes Silva de Albuquerque e \\ Juliana Terra Ribeiro
}

Você está sendo convidado(a) a participar do projeto de pesquisa acima citado. O texto abaixo apresenta todas as informações necessárias sobre o que estamos fazendo. Sua colaboração neste estudo será de muita importância para nós, mas se desistir a qualquer momento, isso não lhe causará prejuízo.

O nome deste documento que você está lendo é Termo de Consentimento Livre e Esclarecido (TCLE). Antes de decidir se deseja participar (de livre e espontânea vontade) você deverá ler e compreender todo o conteúdo. Ao final, caso decida participar, você será solicitado a assiná-lo e receberá uma cópia do mesmo.

Antes de assinar, faça perguntas sobre tudo o que não tiver entendido bem. A equipe deste estudo responderá às suas perguntas a qualquer momento (antes, durante e após o estudo).

\title{
Natureza e objetivos do estudo
}

- O objetivo específico deste estudo é avaliar a percepção dos estudantes de medicina sobre o impacto das disciplinas de Interação, Ensino, Saúde e Comunidade (IESC) e Habilidades Clínicas (HA) para a capacitação dos mesmo na graduação.

- Você está sendo convidado a participar exatamente por ser estudante de medicina do UniCEUB e estar cursando do terceiro ao oitavo semestre

\section{Procedimentos do estudo}

- Sua participação consiste em participar de grupos focais expressando sua opinião de acordo com o que for proposto pelos pesquisadores

- Não haverá gravação de voz, filmagem ou fotos. Qualquer material que contenha informações especificas dos participantes sera destruído ao termino do trabalho.

- Não haverá nenhuma outra forma de envolvimento ou comprometimento neste estudo.

- A pesquisa será realizada no UniCEUB.

\section{Riscos e benefícios}

- Este estudo possui riscos mínimos, sendo relacionados à natureza humana, tais como: desentendimentos entre os participantes, usando-se ou não palavras de baixo calão, durante os grupos focais.

- Medidas preventivas de orientações no início dos grupos focais serão tomadas durante a realização dos grupos. Intervenções podem ocorrer, caso seja necessário, estando o participante sujeito a ser excluído da pesquisa caso não siga as orientações e falte com respeito aos colegas presentes. Isso ocorrerá para minimizar qualquer risco ou incômodo.

- Caso esse procedimento possa gerar algum tipo de constrangimento, você não precisa realizá-lo. 
- Com sua participação nesta pesquisa você poderá contribuir para a análise da contribuição dos eixos de IESC e HA na construção do ensino médico aplicado no UniCEUB além de contribuir para maior conhecimento sobre essas áreas de ensino que compõe a metodologia ativa.

\section{Participação, recusa e direito de se retirar do estudo}

- Sua participação é voluntária. Você não terá nenhum prejuízo se não quiser participar.

- Você poderá se retirar desta pesquisa a qualquer momento, bastando para isso entrar em contato com um dos pesquisadores responsáveis.

- Conforme previsto pelas normas brasileiras de pesquisa com a participação de seres humanos, você não receberá nenhum tipo de compensação financeira pela sua participação neste estudo.

\section{Confidencialidade}

- Seus dados serão manuseados somente pelos pesquisadores e não será permitido o acesso a outras pessoas.

- Os dados e instrumentos utilizados ficarão guardados sob a responsabilidade de Natália Mariana D. S. de Albuquerque e Juliana Terra Ribeiro com a garantia de manutenção do sigilo e confidencialidade, e arquivados por um período de 5 anos; após esse tempo serão destruídos.

- Os resultados deste trabalho poderão ser apresentados em encontros ou revistas científicas. Entretanto, ele mostrará apenas os resultados obtidos como um todo, sem revelar seu nome, instituição a qual pertence ou qualquer informação que esteja relacionada com sua privacidade.

Se houver alguma consideração ou dúvida referente aos aspectos éticos da pesquisa, entre em contato com o Comitê de Ética em Pesquisa do Centro Universitário de Brasília - CEP/UniCEUB, que aprovou esta pesquisa, pelo telefone 3966.1511 ou pelo e-mail cep.uniceub@uniceub.br. Também entre em contato para informar ocorrências irregulares ou danosas durante a sua participação no estudo.

$\mathrm{Eu}$, RG após receber a explicação completa dos objetivos do estudo e dos procedimentos envolvidos nesta pesquisa concordo voluntariamente em fazer parte deste estudo.

Este Termo de Consentimento encontra-se impresso em duas vias, sendo que uma cópia será arquivada pelo pesquisador responsável, e a outra será fornecida ao senhor(a).

Brasília, de de

Participante

Tania Inessa Martins de Resende, 99771763, UniCEUB/39661201

Natália Mariana Diógenes Silva de Albuquerque, 981763656, nmdsalbuquerque@gmaail.com

Juliana Terra Ribeiro, 981574876, julianaterraribeiro@gmail.com 
Endereço dos(as) responsável(eis) pela pesquisa : Tania Inessa

Instituição: UniCEUB

Endereço: Sqn 214 ap 105

Bloco: /NNo: /Complemento: bloco D

Bairro: /CEP/Cidade: Asa Norte, 70873-040.

Telefones p/contato: 99771763

Endereço dos(as) responsável(eis) pela pesquisa : Natalia Mariana

Instituição: UniCEUB

Endereço: rua 10 chácara 179/1 casa 1

Bloco: /№: /Complemento: rua 10- condomínio Ipê

Bairro: /CEP/Cidade: Vicente Pires, 72007395

Telefones p/contato: 981763656

Endereço dos(as) responsável(eis) pela pesquisa: Juliana Terra

Instituição: UniCEUB

Endereço: rua 30 sul apartamento 401

Bloco: /№: /Complemento: lote 6- residencial Deborah Cristina

Bairro: /CEP/Cidade: Aguas Claras, 71929360

Telefones p/contato:V981574876

\author{
Endereço do(a) participante (a) \\ Domicílio: (rua, praça, conjunto): \\ Bloco: /№: /Complemento: \\ Bairro: /CEP/Cidade: /Telefone: \\ Ponto de referência:
}


APÊNDICE C 